\author{
UNIVERSIDADE DE SÃO PAULO \\ INSTITUTO DE PSICOLOGIA \\ DEPARTAMENTO DE PSICOLOGIA SOCIAL E DO TRABALHO
}

VITOR MURAMATSU

Influências da comunicação digital

nos vínculos humanos

SÁO PAULO

2011 


\title{
VITOR MURAMATSU
}

\author{
Influências da comunicação digital \\ nos vínculos humanos
}

Dissertação apresentada ao Instituto de Psicologia, da Universidade de São Paulo, como parte dos requisitos necessários à obtenção do título de Mestre.

Área de Concentração: Psicologia Social e do Trabalho

Orientador: Profa. Dra. Yvette Piha Lehman

SÁO PAULO

2011 


\title{
AUTORIZO A REPRODUÇÃO E DIVULGAÇÃO TOTAL OU PARCIAL DESTE TRABALHO, POR QUALQUER MEIO CONVENCIONAL OU ELETRÔNICO, PARA FINS DE ESTUDO E PESQUISA, DESDE QUE CITADA A FONTE.
}

\author{
Catalogação na publicação \\ Biblioteca Dante Moreira Leite \\ Instituto de Psicologia da Universidade de São Paulo
}

\section{Muramatsu, Vitor.}

Influências da comunicação digital nos vínculos humanos / Vitor Muramatsu; orientadora Yvette Piha Lehman. -- São Paulo, 2011.

$115 \mathrm{f}$.

Dissertação (Mestrado - Programa de Pós-Graduação em Psicologia. Área de Concentração: Psicologia Social) - Instituto de Psicologia da Universidade de São Paulo.

1. Psicologia social 2. Internet (Rede de computador) 3. Relacionamento virtual 4. Pós-modernidade I. Título.

HM251 


\section{FOLHA DE APROVAÇÃO}

Vitor Muramatsu

Influências da comunicação digital nos vínculos humanos.

Dissertação apresentada ao Instituto de Psicologia, da Universidade de São Paulo, como parte dos requisitos necessários à obtenção do título de Mestre.

Área de Concentração: Psicologia Social e do Trabalho

Aprovado em:

\section{Banca Examinadora}

Profa. Dra Instituição: Assinatura:

Prof. Dr. Instituição: Assinatura:

Prof. Dra Instituição: Assinatura: 
Aos meus pais que através do amor, ensinaram seus filhos a serem felizes.

Ao meu irmão Eric, eterno amigo e companheiro.

Ao meu irmão Heitor. Por ser uma dádiva Divina e uma alegria em nossas vidas 


\section{AGRADECIMENTOS}

Aos meus pais, cujo companheirismo frutificou os projetos de amor. Minha mãe Lucia Helena Massako Higashi inspiração de todo meu viver. Meu pai Luiz Noboru Muramatsu que em seu amor infinito se faz presente em toda minha existência

Ao meu irmão Eric Muramatsu, meu melhor amigo e eterno companheiro por todas as alegrias que compartilhamos.

Ao meu irmão Heitor Muramatsu, por ser abençoado.

A Vera Lucia, por fazer parte desta família grande e por todo companheirismo para com meu pai e por nos gratificar com um filho lindo.

A Caroline Ikeda, pelo apoio incondicional em cada cândido gesto de carinho.

A Profa. Yvette Piha Lehman querida orientadora que me conduziu pelas mãos através das veredas da psicologia e compartilhou com desvelo sua sabedoria.

Aos Professores Doutores Marcelo Afonso Ribeiro e Nélson da Silva Júnior pelas valiosas observações no exame de qualificação.

Aos funcionários do Instituto de Psicologia da Universidade de São Paulo que em sua inesgotável dedicação sempre me receberam com um sorriso.

Aos meus amigos Christian Pedruzzi, João Antônio N.R. Neto, Paulo Vargas, Thiago Zambom, Fabio Poles, Felipe Amorim, Raoni Cogo, Caio Alves e Edno Santana que de diferentes formas e apesar da distância, sempre estiveram ao meu lado.

As minhas amigas Paula Dutra, Rita Wu, Fabiana Catanzaro, Camila Maia e Lidiane Leite cuja sensibilidade e carinho ultrapassam qualquer definição.

Ao meu eterno mestre e amigo Domingos Takeshita, cujos ensinamentos tão felizes fazem parte de mim.

A minha avó Ana que me criou e viu este mestrado começar.

A minha avó Sumino que me amava silenciosamente e me ensinou a simplicidade de ser feliz. 
"Uma história que não comportasse nem surpresas, nem coincidências, nem encontros, nem conhecimento, não reteria nossa atenção".

Paul Ricoeur 


\section{RESUMO}

MURAMATSU, Vitor, Influências da comunicação digital nos vínculos humanos. 2011. 150 f. Dissertação (Mestrado) - Instituto de Psicologia, Universidade de São Paulo, São Paulo, 2011.

Controversas opiniões tem sido defendidas no tocante aos efeitos das relações humanas mediadas pelas novas tecnologias da informação e comunicação. Este trabalho procurou elucidar de que maneira os processos próprios da pós modernidade refletidos nas tecnologias da informação e comunicação estariam afetando os relacionamentos humanos com especial atenção para os vínculos humanos. Através da análise de entrevistas constatou-se que tanto o posicionamento dos críticos às TICs quanto os defensores das potencialidades das relações mediadas em redes digitais tinham uma parcela de razão e que os desenvolvimentos deste campo de pesquisa precisam de um olhar aguçado para uma devida análise do contexto.

Palavras Chave: Psicologia Social, Internet, Vínculos, Pós moderno. 


\begin{abstract}
MURAMATSU, Vitor, Idigital Communications Influences over the human bonds2011. $150 \mathrm{f}$. Thesis (Master) - Instituto de Psicologia, Universidade de São Paulo, São Paulo, 2011.

Controversal opinions have been defended about the effects of the human relations mediated by the new technologies of information and communication. This study worked to enlight the manner how the typical post-modernity process reflected into the technologies of information and communication should affect the human relationships with special attention to the human bonds. Through the interview analysis it have been found that both the ICT's critics and defenders have its share of reason and that the developments of this research field need a special look to a right analysis of the context.
\end{abstract}

Key-words: Social Psychology, Internet, Bonds, Post Modern. 


\section{SUMÁRIO}

1. Contextualizando o homem pós-moderno e suas problemáticas. 19

2. Algumas considerações acerca do pós-moderno ....................... 27

2.1. Considerações acerca do debate entre moderno e pós-moderno.............27

2.2. Contexto histórico do surgimento do pós-moderno ................................29

2.3. Características do pós-moderno relevantes ao nosso estudo ...................30

3. As Tecnologias da Informação e Comunicação (TICs) ................ 35

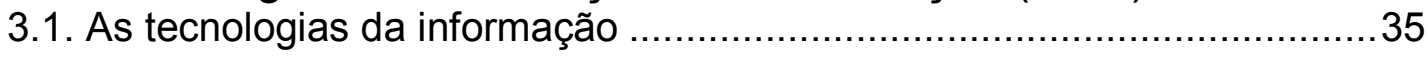

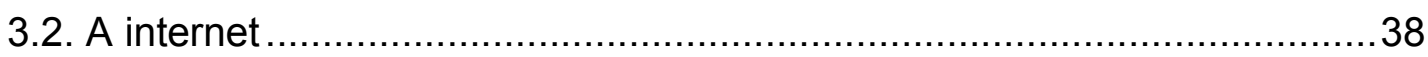

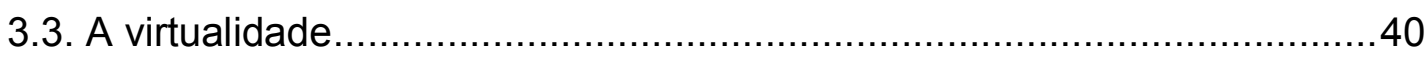

4. Algumas considerações acerca do vínculo............................... 42

4.1. Considerações acerca do conceito de vínculo ....................................42

4.2. Estariam os meios de comunicação digital interferindo nos vínculos? .....43

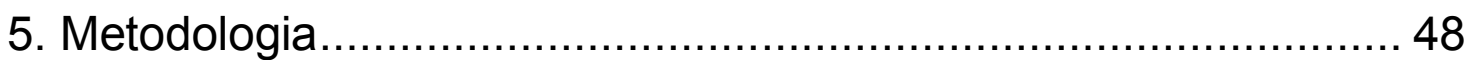

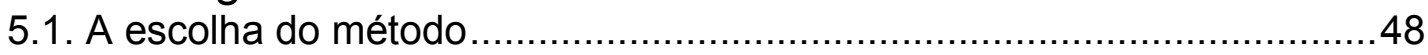

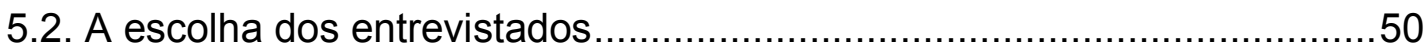

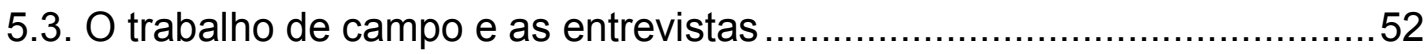

6. Análise e discussão dos dados ............................................... 56

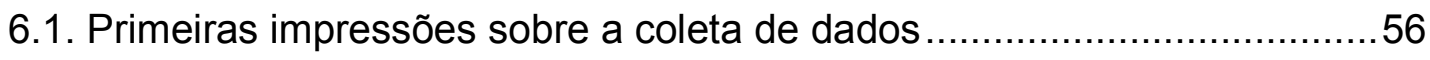

6.2. As redes e as novas formas de vinculação ...........................................61

6.3. TICs, vínculos e políticas......................................................................

7. Conclusões e indicações para um trabalho posterior .................. 88

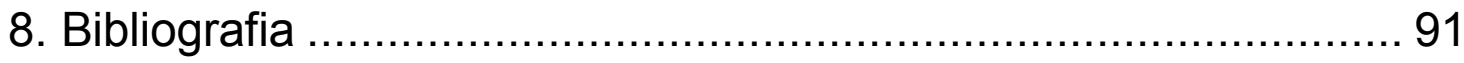

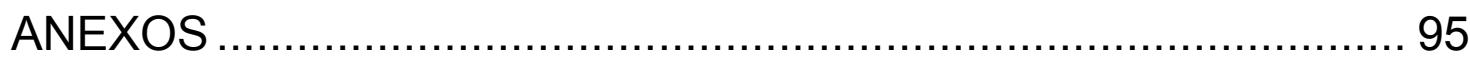




\section{Contextualizando o homem pós-moderno e suas problemáticas}

O avanço das tecnologias da informática, dado principalmente a partir da década de 1980, impôs uma série de mudanças em todas as esferas da vida humana. Dentro da lógica da globalização, os sistemas de informação digital passaram a conglomerar dados e a controlar processos de modo que a automatização do saber e do fazer da vivência humana se tornou cotidiana. Tais alterações não se dão sem efeito na cultura e nos sujeitos. Cada vez mais rapidamente o advento de novas tecnologias intermedeia as relações do homem com seu meio alterando seu modo de viver. A popularização do uso dos computadores pessoais e da internet potencializou uma série de modalidades de comunicação eletrônica que vêm modificando significativamente o modo dos sujeitos se relacionarem com o mundo. A internet, enquanto um meio virtual de informações digitais, se constitui em um amálgama indefinido formado por conexões em rede que, contínua e incessantemente, se expande e se altera. Esse espaço virtual de informações digitais é conhecido como ciberespaço'.

\footnotetext{
1 LEVY, Pierre. A conexão planetária: o mercado, o ciberespaço, a consciência. São Paulo: Editora 34, 2001.
} 
No atual mundo globalizado, regido por um capitalismo neoliberal sem fronteiras, em que os valores e paradigmas tradicionais foram questionados, dando lugar a um individualismo narcisista-hedonista, o sujeito se encontra abandonado, sem parâmetros, largado à deriva num mar de influências globais. Estranho aos processos automatizados que não lhe são próprios, a crise de identidade do sujeito o coloca frente a frente com seu desamparo no mundo, um lugar em que existe passivamente, estranho ao que se processa por estar à margem daquilo que lhe é proposto. Fato revelador do seu mal-estar é a voracidade com que consome coisas e conceitos num afã por tudo aquilo que Ihe é prometido como sentido existencial, mas que é incapaz de, no breve momento do consumo imediato, suprir o desejo que perpetua insatisfeito.

Entendendo o vínculo enquanto produto de um processo singular a cada sujeito, fruto de suas experiências em seu meio social, estamos afirmando a importância do caráter relacional, do encontro com a alteridade na constituição das significações e simbolizações que corporificam e colorem a dimensão do real. Nesse sentido, as vivências da virtualidade, que prescindem da presença do outro - características da sociedade narcísica ${ }^{2}$-,são desprovidas de efetivo contato humano, portanto são incapazes de dar suporte às representações e às simbolizações que são elementos fundamentais na construção do real.

\footnotetext{
${ }^{2}$ MARCUSE, Herbert. Idéias sobre uma teoria crítica da sociedade. $1^{\underline{a}}$ ed. Rio de Janeiro: Jorge Zahar, 1972.
} 
O caráter global e imediato dos conteúdos do ciberespaço altera as formas de vivência e percepção da realidade dos sujeitos que, já privados de parâmetros identitários, são também tolhidos de referenciais temporo-espaciais.

Dentro desse contexto, estariam as formas de relacionamento mediadas pelas Tecnologias da Informação e da Comunicação interferindo nos vínculos humanos? Se sim, em que medida e em que sentido tais efeitos estariam se processando?

A hipótese é a de que nesse cenário globalizado, carente de referenciais duradouros e altamente tecnologizados, os vínculos humanos são afetados profundamente, sendo seus efeitos perceptíveis na subjetividade do sujeito que, alienado de si mesmo, encontra dificuldade de se relacionar com o outro e consigo mesmo (GIDDENS, 1991). Desse modo, a internet se revela como campo profuso de vivências virtuais, e de modos de se relacionar não naturais com consequências na constituição dos laços e dos vínculos, na sua percepção da realidade e na sua vivência no mundo.

Compreendendo que o atual estágio de desenvolvimento do sistema capitalista tem uma história, o trabalho é guiado por um referencial do materialismo histórico e dialético, que procura explicar a dinâmica da sociedade global de produção capitalista, na qual a liberdade do homem é regida pelo valor de troca de sua força de trabalho dentro da situação de mercado. Tal referencial teórico auxiliaria a análise do porquê as atuais formas de relacionamento estão esvaziadas de sentidos, desumanizadas, uma vez que compreende ser inerente 
ao capitalismo que o sujeito transformado em força de trabalho - mercadoria seja esvaziado de sua subjetividade e imbuído de características próprias dos objetos (coisificação). Ao passo que os objetos, de modo fetichista, sejam percebidos e propagandeados como dotados de características subjetivas. (MARX, 1987).

Por suposto, não se pode ter o que é próprio do homem em coisas. Desse modo, o consumo desenfreado de objetos presumidamente providos de características sensíveis, é incapaz de suprir a demanda por conteúdos significativos que só pode se dar por meio do homem na instância comunitária na qual, ao ser reconhecido, se reconhece e se legitima. Nesse sentido, podemos considerar o sujeito que consome desenfreadamente como alienado de si mesmo. Para o materialismo histórico e dialético o capitalismo não gera somente relações de produção capitalistas-mercantis, também produz relações sociais permeadas pela lógica do capital.

A subjetividade do sujeito é fruto dos vínculos estabelecidos em seu meio e dos laços tecidos entre semelhantes em seu contexto sócio-histórico-cultural. Partindo do suposto que a fantasia, alimentada pelo desejo, é de certo modo satisfatória, poderia ela estar sendo preponderante nos relacionamentos virtuais através da internet, evitando assim o confrontamento com o real (do outro e de si mesmo) que é revelado no encontro com a alteridade? Nessa perspectiva, 
como se processaria a constituição do self, se, como afirma Erving Goffman ${ }^{3}$, esse contato com o outro é parte essencial da representação do eu?

Estariam os relacionamentos virtuais potencializando vínculos menos profundos e, portanto, a vivência de sentimentos mais superficiais, efêmeros como a velocidade da internet?

O contexto globalizado, instantâneo e informatizado que tantos conteúdos abarca é incapaz de dar sentido ao homem, o qual se aliena e se perde sem referências (talvez se denominando eclético). É uma globalidade que permite uma comunicação veloz, mas que parece estar afastando os sujeitos do contato propriamente dito.

Tais contradições recebem grandes contribuições da teoria crítica da sociedade de Herbert Marcuse ${ }^{4}$, que percebe a sociedade industrial positivista como irracional em sua produção destruidora. $\mathrm{O}$ autor ressalta que o processo civilizatório está pautado no incessante conflito entre Eros e Tanathos. O impulso de Eros é o de unir os homens em laços permanentes que sejam capazes de constituir a civilização e a humanidade. Tanathos, em contrapartida, é destruidor e se opõe ao movimento civilizatório. Analisando o contexto sócioeconômico e de como as relações humanas foram ao longo da história sendo estabelecidas, Marcuse conclui que em nossa sociedade 0 trabalho realizado

\footnotetext{
${ }^{3}$ GOFFMAN, Erving. A representação do eu na vida cotidiana. 2ª ed. Petrópolis: Vozes, 1983.

${ }^{4}$ MARCUSE, Herbert. Eros e Civilização - uma interpretação filosófica do pensamento de Freud. $5^{\mathrm{a}}$ ed. Rio de Janeiro: Jorge Zahar, 1972.
} 
sem prazer e com esforço é predominante. A ação do homem no mundo que deveria usar de fontes eróticas e destrutivas - expressões de Eros e Tanathos respectivamente - acaba por potencializar preponderantemente a destrutividade, conferindo um caráter destruidor para toda vivência em sociedade. Esse olhar aguçado de Marcuse sobre as incoerências oferece subsídios para uma análise pormenorizada das contradições observadas na vivência humana da virtualidade nos dias de hoje.

Jean-François Lyotard ${ }^{5}$ faz uma análise detalhada dos efeitos da pósmodernidade na vida dos sujeitos, de como a cultura se modificou e quais consequências têm implicado na vida cotidiana. Segundo ele, na mesma medida em que a vivência na pós-modernidade se tornou extremamente complexa, ela se ficou mais frágil.

Outro autor que se debruça sobre a complexidade das relações na pósmodernidade, principalmente sobre a temporalidade, é Zygmunt Bauman ${ }^{6}$. Para ele, a sociedade nos dias de hoje está marcada pelo individualismo e pelo dinamismo e exige pessoas suficientemente fluidas num ambiente de desconstrução das estruturas até então vigentes (instituições, classes, raças, etc.). Tal fluidez afeta sobremaneira os relacionamentos afetivos de modo que a lógica "em rede" do mundo global não se instaura sem dificuldade no âmbito

\footnotetext{
${ }^{5}$ LYOTARD, Jean-François. O pós-moderno. $3^{\text {a }}$ ed. Rio de Janeiro: José Olympio, 1988.

${ }^{6}$ BAUMAN, Zygmunt. Amor líquido - sobre a fragilidade dos laços humanos. $1^{\text {a }}$ ed. Rio de Janeiro: Jorge Zahar, 2004.
} 
afetivo. A velocidade do imediato traz insegurança para a vida amorosa cujos pressupostos, tais como fidelidade e confiança, só se constroem no compromisso do tempo. Sentindo-se descartável, o sujeito tende a viver na superficialidade da virtualidade jamais consolidando laços afetivos mais sólidos.

As contribuições de Sergio Paulo Rouanet ${ }^{7}$ são muito válidas na análise de desdobramentos da questão proposta: estariam as formas de relacionamento mediadas pelas Tecnologias da Informação e da Comunicação interferindo nos vínculos humanos? Elas afetariam de modo diverso diferentes segmentos etários? Afetariam de modo distinto os gêneros? Estaria a internet, dentro da lógica do consumo, contribuindo para a banalização do corpo e do afeto? Estaria o corpo se tornando objeto de consumo e, assim sendo, objetivando as relações humanas, coisificando-as e atribuindo-lhes um caráter descartável, tal como uma mercadoria? Estaria contribuindo para uma erotização precoce dos jovens e adolescentes? Para Rouanet, tais colocações, se procedentes, auxiliariam no entendimento de que o consumo desenfreado de corpos está ligado à não realização afetiva e que somente esta é realmente satisfatória.

Para Richard Sennet ${ }^{8}$, o narcisismo e o hedonismo, característicos dos tempos de hoje, conduzem o homem às paixões dos interesses privados que relativizam e violam toda realidade pela saciação dos desejos, do bem-estar do

\footnotetext{
${ }^{7}$ ROUANET, S. P. Mal-estar na Modernidade. $2^{\mathrm{a}}$ ed. São Paulo: Companhia das letras, 2001.

${ }^{8}$ SENNET, Richard. A corrosão do caráter. 12ª ed. Rio de Janeiro: Record, 2007.
} 
corpo e das sensações. Em contrapartida, Pierre Lévy ${ }^{9}$ acredita que o processo de virtualização ${ }^{10}$ não é apenas deletério, pois implica em descobrir diferentes formas de lidar com novos instrumentos que expandam as possibilidades de se relacionar com os outros e com o mundo. $\mathrm{O}$ autor conclui também que a virtualização utiliza o processo dialético constantemente ao provocar continuamente desdobramentos da identidade e função de entidades reais. Lévy vislumbra um processo natural dos sujeitos no sentido de uma evolução universal conjunta. Nesse panorama, a sociedade em rede seria um movimento de envolvimento, interdependência e complementariedade do homem, uma perspectiva positiva de cooperação e prosperidade. Para Lévy, o mal-estar dos sujeitos nos dias de hoje seria denotativo das adaptações rumo a este objetivo.

\footnotetext{
9 LÉVY, Pierre. A conexão planetária: o mercado, o ciberespaço, a consciência. São Paulo: Editora 34, 2001.

${ }^{10}$ LÉVY, Pierre. O que é o virtual?. São Paulo: Editora 34, 1996. p.15-24.
} 


\section{Algumas considerações acerca do pós-moderno}

2.1. Considerações acerca do debate entre moderno e pós-moderno.

Não há, nas ciências humanas, um consenso a respeito da nomenclatura para a atual fase do desenvolvimento social, cultural, político e econômico. As discussões em torno dessa temática têm possibilitado diversos termos com suas diferentes teorias subjacentes, umas mais consistentes que outras. Tais discussões foram mais efusivas ao longo dos últimos trinta anos, podendo-se destacar a discussão levantada pela publicação de "La condition postmoderne" de Lyotard, em $1979^{11}$, e da reação de Habermas aos textos de Foucault sobre o pós-moderno, concentrados principalmente em "Der Philosophische Diskurs der Moderne"12, escritos no ano seguinte à morte do filósofo francês.

Podemos, de antemão, dividir as diversas discussões a respeito do impasse entre moderno e pós-moderno em duas grandes vertentes. A primeira é composta por aqueles que acreditam que o moderno está acabado, tendo em vista que os projetos da era moderna estão extintos porque se exauriram, pois jamais foram alcançados ou eram ilusórios. Importante ressaltar nessa categoria a influência do pós-estruturalismo francês no pós-moderno (por exemplo,

\footnotetext{
${ }^{11}$ LYOTARD, Jean-François. O pós-moderno. $3^{\mathrm{a}}$ ed. Rio de Janeiro: José Olympio, 1988.

${ }^{12}$ HABERMAS, Jürgen. Der Philosophische Diskurs der Moderne. Frankfurt: Suhrkamp, 1985.
} 
Lyotard, Baudrillard, Guatarri, Deleuze, Derrida, Lacan). Cabe aqui, somente a título de esclarecimento, citar que há uma diferença marcante entre pósestruturalismo e pós-moderno, caracterizada pelo fato daquele ter sido principalmente uma sistematização teórica focada nas regras de linguagem e significação. Ao passo que o pós-moderno tem sentido muito mais abrangente e ultrapassa a esquematização teórica e os limites da discussão científica (influenciado pelo pós-estruturalismo) para se tornar tema central de todo o pensar relativo aos acontecimentos sociais, culturais, estéticos, políticos e econômicos dos dias de hoje ${ }^{13}$. A segunda vertente apregoa que o projeto moderno ainda está em andamento, sendo que o panorama atual de mudanças, característicos dessa sua fase crepuscular é chamado de alta modernidade ou modernidade tardia por alguns pensadores ${ }^{14}$.

Independentemente das diferenças apresentadas pelos defensores do moderno e do pós-moderno, ambos os pontos de vista concordam que o mundo mudou e que nos encontramos num cenário em que os projetos da modernidade não mais se sustentam.

Adotaremos para nosso estudo o termo pós-moderno por dois motivos: em primeiro lugar, não pela afinidade com as teorias defensoras do termo, mas pela simplicidade e generalidade que este termo se refere a um estado diferente

\footnotetext{
${ }^{13}$ PETERS, Michael. Pós-estruturalismo e filosofia da diferença: uma introdução. $1^{\text {a }}$ ed. Belo Horizonte: Autêntica, 2000.

${ }^{14}$ Entre outros, podemos citar Jürgen Habermas e Anthony Giddens.
} 
do cenário tido como moderno. Simplicidade esta se comparada aos termos alta modernidade ou modernidade tardia, sabidamente tendenciosos de teorias especificas com características peculiares a um estado diferente do cenário tido como moderno. Em segundo lugar, não é foco deste estudo discutir as minúcias do embate entre defensores do termo moderno e pós-moderno motivado sobretudo pela constatação de que o que nos é útil dessa discussão é comum a ambos, as profundas alterações dadas a partir da herança insidiosa do iluminismo que geriu o projeto moderno nas suas consequências mais velozes na infraestrutura, no modo econômico capitalista industrial bem como nas modificações na sociedade e nas instituições, ressaltando nesse tocante a secularização e o racionalismo.

2.2. Contexto histórico do surgimento do pós-moderno

Lipovetsky $^{15}$, assim como Lyotard, indica o surgimento da pósmodernidade a partir do final da década de 1950, caracterizado na Europa pelo fim de sua reconstrução. Lipovetsky denominou-a como "civilização do desejo". Segundo o autor, o substrato histórico dessa revolução está intimamente atrelado aos rumos que o capitalismo tomou em direção à estimulação eterna da demanda, da mercantilização, da multiplicação indefinida das necessidades. De

${ }^{15}$ LIPOVETSKY, Gilles. A felicidade paradoxal: ensaio sobre a sociedade de hiperconsumo, $1^{\text {a }}$ ed. São Paulo: Companhia das letras, 2007. 
acordo com todos os demais teóricos citados neste trabalho, o capitalismo de consumo, impondo uma nova relação entre as coisas e as pessoas, extingue a ideia das economias de produção que ainda se resguardavam da ideologia do consumo em si e do valor de uso real dos objetos.

Os defensores da "alta modernidade" se baseiam na historicidade dos acontecimentos que culminaram nos dias de hoje. O ideário iluminista de liberdade e igualdade que, na modernidade se caracterizou pelo projeto antropocêntrico no indivíduo, funda o eixo norteador dos eventos desse cenário. Numa modernidade em que a sociedade atomista toma forma, a própria ideia e sentimento de uma reunião de indivíduos alimentou a ciência. O entendimento de Weber a respeito da modernização perpassa pelas diversas e mútuas racionalizações globais ocorridas nas esferas política, econômica e cultural. Nesse sentido, as teses weberianas dão total respaldo aos acontecimentos que a partir de 1950 alteraram as formas até então estabelecidas de entendimento e vivência do cenário global.

\subsection{Características do pós-moderno relevantes ao nosso estudo}

Uma das características mais importantes do pós-moderno relevante ao nosso estudo é a progressiva perda de referenciais históricos. De maneira inédita, há na historiografia do homem diversos agentes que se coadunam de modo a pulverizar nossa percepção de tempo histórico (consequentemente de 
espaço vivido), retirando o eixo fundamental de nossa inserção num contexto com passado definido e futuro plausível. Para Lyotard $^{16}$, é a partir do fim dessa axial metanarrativa que se pode pensar as profundas consequências do desamparo do homem na pós-modernidade.

Giddens ${ }^{17}$ articula que o desenvolvimento social moderno se baseia nas descontinuidades das instituições sociais modernas com suas características peculiares e diferentes do modo tradicional. A apreensão da descontinuidade seria fator revelador das imbricações próprias do presente cenário. Giddens destaca que os modos de vida na modernidade não têm precedentes nos tipos tradicionais de ordem social. Nesse sentido, nega as formas totalizadas de evolucionismo social e convida a perceber nas mudanças de ritmo da história e no escopo das mudanças, as características interconectivas das instituições modernas.

Para Baudrilard ${ }^{18}$, a sociedade de consumo, presente no pós-moderno, perdeu passivamente o interesse nas relações significativas, dadas ao longo do tempo e com uma história, e foi tomada por um insaciável desejo e uma ênfase no presente e no bem-estar imediato, das rápidas e efêmeras sensações do corpo. Esse hedonismo desinveste imediatamente a atuação política e o

\footnotetext{
${ }^{16}$ LYOTARD, Jean-François. O pós-moderno. 3aㅡ ed. Rio de Janeiro: José Olympio, 1988.

${ }^{17}$ GIDDENS, Anthony. As consequências da modernidade. $6^{\underline{a}}$ ed. São Paulo: Editora da Unesp, 1991.

${ }^{18}$ BAUDRILLARD, Jean. A sociedade de consumo. 1르 ed. Lisboa: Edições 70, 1975.
} 
engajamento social, isolando o indivíduo cada vez mais em direção a seu conforto momentâneo. Segundo Lipovetsky, o lazer substituiu a revolução.

Lipovetsky, em razão da transformação pela qual a sociedade de consumo passou, denominou a sociedade atual como hiperconsumista, tendo característica principal uma economia centrada no consumidor. Essa constatação parte da transição do modelo fordista com produtos padronizados para uma economia de variedade e de renovação, na qual algumas características qualitativas, tais como pesquisas de mercado e satisfação do cliente, passaram a definir melhor a competitividade das empresas. Nesse sentido, o autor afirma que a economia passa de um modelo centrado na oferta para uma economia centrada na procura.

A sociedade hiperconsumista, que para o autor toma forma, traz consigo os ideais de felicidade, prazer e gozo advindos do consumo dos recursos materiais, que também não deixam de fornecer prestígio e destaque social. Tais recursos materiais são passíveis de serem colocados em questão desde agora, tendo em vista que uma característica central da nossa atual sociedade da informação é a transição de uma economia baseada na produção e troca de bens materiais pra uma economia calcada sobretudo no fluxo - controle, desenvolvimento, estratégia - de informação. Com isso, começa a se desenvolver um modelo de um consumidor mais individualista que tende a buscar produtos mais personalizados com o intuito de se diferenciar da grande maioria. 
Nesse contexto, a chamada lógica subjetiva do neoindividualismo, em que há um desejo narcísico de satisfação para si, é "ser uma pessoa de qualidade" que veste ou faz uso de peças raras, inacessíveis à maior parte da população. Perante esse sujeito, um bombardeio de imagens e mensagens advindos da mídia, reforçam a postura do consumidor, aguçando ainda mais as sensações e emoções que podem surgir das aquisições feitas, bem como agem como mola propulsora às realizações da fantasia. $\mathrm{O}$ ataque realizado pelo marketing sensorial a partir das experiências do sujeito é intenso e sedutor, já que o prazer da novidade e a promessa do sentir como um ser humano único e especial são os desejos que atualmente permeiam as pessoas.

Indo além do hiperconsumismo, Lipovetsky vislumbra uma sociedade pós-hiperconsumista calcada em uma profunda mudança de valores.

Com o capitalismo de consumo, o hedonismo se impôs como um valor supremo e as satisfações mercantis, como o caminho privilegiado da felicidade. Enquanto a cultura da vida cotidiana for dominada por esse sistema de referência, a menos que se enfrente um cataclismo ecológico ou econômico, a sociedade de hiperconsumo prosseguirá irresistivelmente em sua trajetória. Mas, se novas maneiras de avaliar os gozos materiais e os prazeres imediatos vierem à luz, se uma outra maneira de pensar a educação se impuser, a sociedade de hiperconsumo dará lugar a outro tipo de cultura. A mutação decorrente será produzida pela invenção de novos objetivos e sentidos, de novas perspectivas e prioridades na existência. Quando a felicidade for menos identificada à satisfação do maior número de necessidades e à renovação sem limite dos objetos e dos lazeres, o ciclo do hiperconsumo estará encerrado. 
Essa mudança sociohistórica não implica nem renuncia ao bem-estar material, nem desaparecimento da organização mercantil dos modos de vida; ela supõe um novo pluralismo dos valores, uma nova apreciação da vida devorada pela ordem do consumo volúvel."19 (Lipovetsky, 2007)

O cuidado que o autor tomou ao escolher suas palavras aparentemente Ihe resguardaria, em parte, da responsabilidade de seus termos e da tenacidade de suas argumentações nos trechos em que aparecem "enquanto" e "a menos que". Entretanto, não foi esse o objetivo; seu discurso dialético e próprio de uma mentalidade questionadora não hesita em afirmar a inevitabilidade da revolução pós-consumista. Um tempo em que a centralidade do consumo dará lugar a uma mudança cultural com uma profunda reavaliação dos gozos imediatos e momentâneos. Segundo o autor, assim como a opção pelo consumo é histórica e datada, também é limitada a fenecer nessa historiografia. Ele acredita em democracias pós-consumistas, nas quais a cultura e a educação façam seu trabalho longo e enraizado e frutifiquem numa sociedade em que o hedonismo e o consumo irrefreado, já não sejam sinônimos artificiais de qualquer tipo de satisfação ou felicidade reais.

\footnotetext{
19 LIPOVETSKY, Gilles, A felicidade paradoxal: ensaio sobre a sociedade de hiperconsumo. $1^{\text {a }}$ ed. São Paulo: Companhia das letras, 2007. p. 367-368.
} 


\section{As Tecnologias da Informação e Comunicação (TICs)}

\subsection{As tecnologias da informação}

As tecnologias da informação e comunicação normalmente referidas pela sigla TICs em português, ou ICT (Information and Communication Technologies) em inglês, englobam genericamente todas as tecnologias que estão envolvidas e relacionadas com a criação, manejo e difusão da informação. Englobando hardware $^{20}$, software ${ }^{21}$ e telecomunicações. A sigla TI (tecnologias da informação) não contemplava o caráter unificado, integrado e inter-relacionado das comunicações, por outro lado o termo TICs exprime melhor a ideia de convergência de diferentes tecnologias e sistemas trabalhados em conjunto para a comunicação e manejo das informações.

Diversos elementos povoam o que podemos chamar de tecnologias da informação e tecnologias da inteligência ${ }^{22}$. Algumas tecnologias se referem especificamente a equipamentos computadorizados, informacionais e em rede, enquanto outros se referem a modos cognitivos e interfaces (softwares) para lidar com esses equipamentos e sistemas.

\footnotetext{
${ }^{20}$ Parte física e estrutural dos aparelhos tecnológicos.

${ }^{21}$ Parte lógica dos aparelhos tecnológicos. Os programas.

22 Pierre Lévy (1998).
} 
A sociedade atomizada que tratamos neste trabalho está interconectada por diversos elementos, dentre eles a internet é o meio prevalente de troca de dados e de comunicação. Num sentido mais abrangente e pessoal, um equipamento de conexão moderno muito difundido é o telefone celular, capaz de se conectar à internet em qualquer lugar onde o portador esteja, colocando-o em contato com outros usuários da rede por meio de seus dispositivos de relação. Um desses dispositivos disponíveis há tempos, mas ainda em voga, são os sites de chat $^{23}$ que, em sua essência, pouco mudaram desde suas primeiras versões no $\mathrm{IRC}^{24}$ (interface com um campo em que apareciam os nomes de usuários presentes no "espaço virtual" e um outro em que se lia os conteúdos escritos pelos usuários e se inseria o texto a ser enviado). Atualmente, alguns chats permitem o uso de dados de voz e de imagem com a utilização de microfones e webcams, mas em sua essência os usuários continuam se "relacionando" sem sair da frente de seus computadores.

Os programas de comunicação instantânea funcionam similarmente, no entanto tem a diferença de que a lista de contatos pode ser previamente escolhida ou excluída. Blogs são como sites pessoais nos quais se pode divulgar textos e imagens. São comumente categorizados por temas e assuntos;

23 BAUMAN, Zygmunt. Amor líquido: sobre a fragilidade dos laços humanos. $1^{\text {a }}$ ed. Rio de Janeiro: Jorge Zahar, 2004.

${ }^{24}$ COSTA, Ana Cláudia A. IRC: uma nova alternativa para as relações entre as pessoas, dissertação (Mestrado em Psicologia Clínica), Departamento de Psicologia, Pontifícia Universidade Católica do Rio de Janeiro, Rio de Janeiro, 2001. 
alguns blogs se comprometem com o comentário crítico de fatos mundiais, outros de considerações acerca do pensamento na contemporaneidade, alguns são especializados em crítica de literatura, música e arte e, a grande maioria trata de assuntos pessoais, servindo de instrumento para uma análise do narcisismo nos tempos da virtualidade.

As redes sociotécnicas também são sites específicos que possibilitam a criação de uma página pessoal dentro desse sistema e que normalmente visam aproximar os usuários de acordo com suas afinidades através de comunidades virtuais, amigos em comum ou região. A ascensão das redes sociotécnicas, longe de ser um modismo, parece se confirmar além mesmo de uma possível tendência pra se consolidar como uma das formas mais genuínas de agregação espontânea no meio virtual. Não obstante os tipos de redes sociotécnicas têm se diversificado e especializado. A maior das redes sociotécnicas, o Facebook, é uma rede genérica. Outras, como o MySpace, têm uma interface mais artística e, por isso mesmo, são povoadas por pessoas ligadas à música e às artes. O Linkedln é uma rede social para contatos profissionais. No Brasil, o Orkut é a rede social mais famosa e numérica. Outra modalidade de comunicação em rede de contatos que alia o uso de e-mail, celular e internet é o Twitter, site no qual os usuários têm uma página pessoal que comporta comentários de até 140 caracteres enviados imediatamente aos seguidores (followers) ${ }^{25}$, que se

\footnotetext{
${ }^{25} \mathrm{O}$ Twitter tem um sistema diferente das demais redes sociais. Cada usuário pode seguir as novidades de outro usuário mediante a aprovação deste, mas não há obrigatoriedade de
} 
informam de pronto sobre a atualização. Uma interessante característica do Twitter a ser analisada neste trabalho é sua capacidade de atingir todos seus contatos a partir do envio de uma mensagem SMS ou de um e-mail de seu celular para o site. As pessoas podem descrever, minuto a minuto, onde quer que estejam, suas atividades mais rotineiras (cansativa e necessária interatividade) e da mesma maneira acompanhar os acontecimentos relatados nas vidas daqueles que seguem. O Twitter é um expoente das TICs, comportando e portando uma miríade de aplicações e ferramentas midiáticas interagindo com as mais diferentes interfaces.

\subsection{A internet}

A internet, enquanto elemento de análise, nos permite diversas considerações. Em primeiro lugar, é importante destacar sua principal característica a ser analisada: a de que ela carrega o paradoxo de ser e não ser, carrega a dualidade aparência-essência, duas características valiosas a seu respeito. Mesmo sendo uma instância não existente fisicamente, senão nos backbones ${ }^{26}$ que suportam sua estrutura e nos hubs e servidores que guardam e distribuem parte de seus conteúdos, a internet se corporifica como um "lugar" -

reciprocidade dessa relação. Pessoas famosas e formadores de opinião costumam ter muitos seguidores, porém seguem apenas aqueles que lhes interessam.

${ }^{26}$ Equipamentos de alta capacidade de administração e difusão de conteúdos em rede. 
ainda que difuso - e da mesma maneira tem uma temporalidade própria dos meios binários computacionais, a temporalidade do imediato. Esses dois parâmetros, tempo e espaço na internet, possibilitam o paradoxo de existência e não existência do que podemos chamar de espaço virtual (a ser tratado no próximo tópico). Em segundo lugar e complementarmente, a aparente concretude e multiplicidade encontrada na rede têm diversos limitantes reais. Todo e qualquer conteúdo nela contido é fruto de um input de dados; algo específico e recortado daquilo que é real e há no mundo, incorrendo, dessa maneira, que por mais que esses conteúdos sejam complementares e interconectados sempre serão recortes difusos e pulverizados de apreensões da realidade pontuais. A internet, com sua avassaladora influência em todos os espaços da vida cotidiana e com sua opressiva presença no dia a dia de todo o globo, tem sua estrutura física baseada em alguns poucos backbones e sua aparente robustez é na verdade ilusória. A maneira aparentemente fluida e natural com que os equipamentos da tecnologia vinculam o homem à rede parece conferir àquele a capacidade de domar o instrumento e a rede de uma maneira cada vez mais própria e orgânica, com uma humanidade e organicidade não próprias a ela. Subjaz a essa percepção uma profunda falácia e um paradoxo visível já apontado em Marx, passando pela escola de Frankfurt e tantos outros teóricos materialistas que concordam com o fetichismo da mercadoria e da reificação. No entanto, há um agravante: a internet, enquanto 
tecnologia da inteligência ${ }^{27}$, é mais insidiosa que as demais mercadorias conhecidas até hoje.

\subsection{A virtualidade}

A virtualidade, como a pretendemos trabalhar aqui, perpassa por uma explicação breve sobre alguns aspectos importantes de serem pormenorizados.

Diferentemente do pobre entendimento de que o real se opõe ao virtual, tomando o virtual como ausência de realidade e presença, devemos pensar na diferença entre possível e virtual. Citando Lévy (1996):

O possível já está todo constituído, mas permanece no limbo. O possível se realizará sem que nada mude em sua determinação nem em sua natureza. É um real fantasmático, latente. O possível é exatamente como o real: só Ihe falta a existência. [...] Já o virtual não se opõe ao real, ma sim ao atual. Contrariamente ao possível, estático e já constituído, o virtual é como o complexo problemático, o nó de tendências ou de forças que acompanha uma situação, um acontecimento, um objeto ou uma entidade qualquer, e que chama um processo de resolução: a atualização.

A atualização seria a resolução, de alguma maneira, que parte de uma configuração dinâmica de forças e finalidades. A virtualização nesse tocante

27 LEVY, Pierre. Tecnologias da inteligência. São Paulo: Editora 34,1998. 
seria o movimento inverso da atualização. É trazer um conteúdo pontual a seu estado virtual de potência e de possíveis. A virtualização reconfigura a ênfase do atual, terminado a multiplicidade do ontológico.

A virtualização, como se pode apreender, tem como característica principal remontar o atual às suas potencialidades, mas incorre que, dessa maneira, retira também o aspecto presencial do conteúdo que desprende do presente. É esse o aspecto mais interessante da virtualização e elemento central deste estudo para compreender de que maneiras os relacionamentos via internet afetam a subjetividade dos usuários. 


\section{Algumas considerações acerca do vínculo}

4.1. Considerações acerca do conceito de vínculo

O conceito de subjetividade, que neste trabalho é discutido em vista de suas interações com os meios virtualizados, pode ser resumidamente entendido como uma característica humana peculiar a cada sujeito em sua história de vida, seja no seio de um ambiente social formado por referentes estruturados capazes de consolidar uma historiografia de seu estar no mundo e de seus semelhantes, seja ao encontrar e reconhecer entre os limites do público e do privado a instância comunitária da qual também retira e doa significações, identificações e simbolizações. Assim procedendo, o processo subjetivo, eminentemente psíquico, possibilita a internalização dos objetos que dão concretude ao real.

Uma leitura psicanalítica dos desenvolvimentos e desdobramentos de uma subjetividade coesa e bem-estruturada compreende as questões relativas à estruturação e à relação de intersubjetividade com o objeto que são centrais para formação e finalização de um processo de simbolização que permitiria faculdades de pensamento mais próximas da realidade. Os processos identificatórios corporificados em personagens e instituições concretas - família e sociedade, por exemplo - servem como ideais modelos doadores de padrões socialmente aceitos e reconhecidos de valores, comportamentos, crenças, 
costumes, interdições, etc. O processo psíquico desse desenvolvimento na cultura e na sociedade é específico, singular a cada indivíduo e perpassa por suas experiências e maneiras de lidar com os conflitos da dinâmica pulsional (suas defesas, angústias, bloqueios, projeções, fantasias, etc.) em meio aos objetos que povoam sua vida psíquica.

4.2. Estariam os meios de comunicação digital interferindo nos vínculos?

A partir da constatação central de que o esfacelamento dos referenciais comunitários colocou o homem pós-moderno numa condição de desamparo sem precedentes, levantamos as seguintes hipóteses:

Para Sennet ocorre um profundo deslocamento na ideologia da intimidade, iniciada no século XIX, impulsionada sobretudo pelo capitalismo, que atomizou os consumos, e pela credibilidade secular, que minimizou a moralidade às sensações e percepções da mesma forma que o projeto iluminista de caráter fora suplantado pela personalidade. Tais mudanças induziram as pessoas a buscar significações pessoais em situações impessoais, em objetos e nas próprias condições objetivas da sociedade, incorrendo no retorno do sentido à esfera do privado. O homem público paulatinamente perderia sua capacidade de se relacionar com profundas consequências para sua saúde psíquica e capacidade de reconhecimento e convívio entre iguais. 
Alguns fenômenos recentes, tais como o crescente isolamento dos indivíduos em seus trabalhos, seus lares e lazeres, parecem corroborar a hipótese de Sennet. Se o retorno à esfera do privado, numa primeira leitura, é de desinvestimento do homem no âmbito do comunitário, em suas habilidades interpessoais e nos processos de relação socialmente estruturados, parece que a perda da capacidade de se relacionar, consequência primeira, paradoxalmente acaba por conduzir aos seus mais danosos efeitos justamente na esfera do privado, instância que presumidamente resguardaria alguma consistência e segurança no investimento direto e incessante em si mesmo.

O referencial de tempo se perde no imediato da conexão em rede de modo que também a noção de espaço fica cindida, nesse contexto, de múltiplas mensagens e experiências fragmentadas e pulverizadas. A noção de espaço se pluraliza em espaços paralelos coexistentes, e instaura-se nessa devassidão de pseudo-parâmetros um processo contínuo de ser que em nada contribui para um desenvolvimento, contato ou possível autoconhecimento. Esse estado é referido como esquizofrênico ${ }^{28}$ por diversos autores.

O indivíduo em contato direto com a virtualidade, tolhido de seus referenciais essenciais, importa para sua vida psíquica essa mesma desordem. Está fadado ao fracasso em suas tentativas de lidar consigo mesmo, já que a

\footnotetext{
${ }^{28}$ Nicolaci-da-Costa, Ana Maria. "O cotidiano nos múltiplos espaços contemporâneos". Em Psic.: Teor. e Pesq, vol. 21, nº 3, Brasília, set./dez. de 2005.
} 
temporalidade do mundo psíquico não é a mesma da temporalidade do imediato do mundo digital. Bem como o espaço sensível e cognoscível do real não é o mesmo dos "espaços" virtualizados. O homem, tendo que lidar com a dinâmica computacional a todo tempo, começa a considerar a instância do virtual, do vir a ser e do ser em potência como um processo cotidiano e aceitável. Aceitando a lógica de viver em potência, jamais atinge a satisfação e tampouco gozos parciais em que possa se pautar para minimamente dar alguma consistência à sua existência.

Isolado e privado da capacidade de se relacionar apropriadamente por não mais encontrar recursos que o instrumentalizem e capacitem a buscar a já incipiente esfera social, o indivíduo se vê incapaz de corporificar as simbolizações e significações da coletividade que dão consistência para o real. A ausência desses atos públicos do contrato social na instância comunitária que formataria um sistema coeso ocasiona uma brutal experiência ao indivíduo clivado quando de seu contato com o social sem a instância do real.

A importação do modelo de consumo irrestrito e insaciável ${ }^{29}$ de produtos aos conteúdos da internet aumentou exponencialmente a lógica do "ser em potência". Aquele consumo fetichista da mercadoria, teorizado por Marx e pelos demais histórico-dialéticos que o seguiram e desenvolveram essa ideia, na era da informação, tem uma mudança radical. Se em certa medida os produtos

\footnotetext{
${ }^{29} \mathrm{LASCH}$, Christopher. O mínimo eu: sobrevivência psíquica em tempos difíceis. São Paulo: Brasiliense, 1999.
} 
materiais comercializados guardavam significações estranhas e impróprias dos objetos, minimamente eram objetos palpáveis e reais que se compravam e consumiam em lojas físicas e lugares definidos por suas ruas e paredes. Os produtos comercializados nos tempos de internet não obrigatoriamente carregam essa materialidade. As vendas feitas pela rede se dão por meio de muitos canais digitais, os mais comuns são os sites de lojas virtuais (que podem ou não existir fisicamente). Assim como as lojas são virtuais, os produtos comercializados também podem não ter consistência material. Se em algumas lojas é possível comprar uma geladeira ou um livro pela internet, outros produtos, que só existem dentro dos sistemas computacionais, também são comercializados - livro digital, música digital, álbum de figurinhas virtual e até mesmo casas virtuais ${ }^{30}$.

A mais recente febre da internet em sites de venda são as páginas de compras coletivas. Dentro da tendência de redes e de agregação de pessoas com interesses semelhantes, surgiram sites que desenvolveram uma nova estratégia de venda: a página anuncia determinado produto a um preço menor que o normalmente comercializado, e os usuários dessa rede podem assinalar o interesse pelo produto. Atingido o número mínimo de interessados, o produto é vendido. A lógica desse sistema é simples: o comerciante estabelece um valor abaixo do mercado, porém prevê grandes quantidades de vendas, mantendo

\footnotetext{
${ }^{30}$ Comércio realizado no Second Life e em jogos sociais, por exemplo, fazendinha do Orkut.
} 
assim seu lucro e aliando um marketing inovador que divulga sua marca e seus produtos ou serviços.

Assim como as redes sociotécnicas, os sites de compras coletivas também se especializaram. Há páginas para interessados em viagens, compras de utensílios, roupas, restaurantes, etc. Os sites de compras coletivas exploram a ideia da promoção, do consumo constante e da pretensa satisfação neste consumo. As promoções veiculadas são diárias e tem duração determinada, sendo para este estudo especificamente exemplar no contexto em que o indivíduo se encontra nos dias de hoje.

A internet se configura como cenário por excelência, na qual se processam e se visualizam as consequências de todo um contínuo de desconstruções e abandonos do investimento no "eu social" e do surgimento da sociedade narcísica e hedonista, sendo possivelmente seu agente mais imediato, mas não único, das implicações sobre a subjetividade. 


\section{Metodologia}

\subsection{A escolha do método}

A ideia inicial, que já constava no projeto de pesquisa deste mestrado, era realizar a coleta de dados mediante entrevistas. Durante o andamento do trabalho, entretanto, os volumosos dados quantitativos, esteticamente bem apresentados em organizadas tabelas e gráficos, oriundos de instituições como

o CETIC.BR ${ }^{31}$ (Centro de Estudos sobre as Tecnologias da Informação e da Comunicação) e outros órgãos internacionais, tais como Unesco ${ }^{32}$ (United Nations Educational, Scientific and Cultural Organization) ou ITU ${ }^{33}$ (International Communications Union), considerou-se interessante fazer uma pesquisa teórica somada a dados quantitativos advindos de questionários enviados por e-mail ou rapidamente aplicáveis. Tendo em vista, entretanto, as particularidades do objeto de estudo, essa metodologia não parecia interessante para uma dissertação de mestrado e foi posta de lado, após o exame de qualificação, em detrimento da técnica de entrevista, notadamente mais adequada aos propósitos deste estudo.

\footnotetext{
${ }^{31}$ http://www.cetic.br.

32 http://www.unesco.org.

${ }^{33}$ http://www.itu.int.
} 
Não pretendendo focar a discussão sobre a ênfase nos dados quantitativos das hard sciences e da validade das análises qualitativas das soft sciences, é válido ressaltar apenas que a metodologia de pesquisa qualitativa em psicologia tem suas particularidades. Ao lidar com o humano e sua história, a atenção recai sobretudo no caráter vívido dos conteúdos advindos do trabalho de campo. A apreensão desses elementos só é possível mediante uma “consciência aumentada” (Becker, 1999), crítica aos limites quantitativos. Nesse ínterim, o panorama do desenvolvimento da pesquisa qualitativa apresentado por Bogdan \& Bilken (1994) e Denzin \& Lincoln (2006) contextualiza e autoriza as argumentações acerca das escolhas teórico-metodológicas presentes neste trabalho. As próprias características do objeto de estudo e seus vínculos exigiam uma metodologia de coleta de dados que contemplasse o posicionamento da relação de dois seres humanos.

Apoiado e justificado, sobretudo por Geertz (1989) e Bourdieu (1993), este estudo reafirma os princípios da pesquisa num trabalho de campo consciente de suas influências e limitações, comprometido principalmente com um registro não documentado das relações e processos e constituído a partir de imbricamentos complexos, interpretações possíveis e suas consequências. Geertz cita que uma das características desse trabalho é a interpretação do fluxo do discurso social. As entrevistas semiestruturadas preencheram com propriedade os requisitos necessários para uma apreensão ampla e sensível dos dados. O relato oral, segundo Queiroz (1992), contém "a vivacidade dos 
sons, a opulência dos detalhes, a quase totalidade dos ângulos que se apresenta todo fato social [...] para captar o não explícito, quem sabe mesmo o indizível". A socióloga se aproxima profundamente de nossos objetivos quando ressalta que "o interesse deste último [o pesquisador] está em captar algo que ultrapassa o caráter individual do que é transmitido e que se insere nas coletividades a que o narrador pertence". Foi justamente essa descoberta que deu o salto qualitativo desta pesquisa. A entrevista na pesquisa qualitativa em psicologia social se vale do repertório de conhecimentos próprios da psicologia. O relacionamento entre o entrevistador e o entrevistado está atravessado por projeções. É preciso certo manejo e preparo para lidar com o conteúdo que surge no discurso e ter atenção flutuante quanto aos comentários. Estamos buscando não somente o que a fala, a narração diz, mas também aquilo que ela não diz, as pausas, os silêncios, a ênfase dada em diferentes momentos é tão valiosa quanto as palavras ditas. Postura, olhares e expressões também fazem parte desse rico repertório, proporcionado pelo encontro no qual se dá a entrevista.

\subsection{A escolha dos entrevistados}

Partindo das sugestões feitas no exame de qualificação, o trabalho foi direcionado para a realização de entrevistas semiestruturadas e pautadas por um roteiro de perguntas-chave que não obrigatoriamente foi seguido, pois optou- 
se por acompanhar o desenrolar particular das narrativas de cada um dos entrevistados.

Num primeiro momento, a escolha dos participantes foi orientada pela sua visibilidade nas mídias, o seu engajamento e a atividade no mundo digital e sua relação com algum tema de interesse. Esses critérios excluíam, entretanto, grande parte do público consumidor e gerador de conteúdos da internet que também eram do interesse da pesquisa. Para abarcar toda a necessidade desta pesquisa, o evento Campus Party Brasil IV ${ }^{34}$ (CPBR4) se apresentava como o ambiente perfeito para encontrar pessoas de varias áreas e interesses, envolvidos de diferentes maneiras com os meios digitais, mas todos relacionados com o tema, sendo assim entrevistados em potencial.

Alguns contatos foram feitos previamente ao início do CPBR4 com o objetivo de agendar uma entrevista durante o evento, contudo, por diversos motivos, os possíveis entrevistados não participaram do estudo. Foi necessário selecionar no último instante, naquele ambiente, outros possíveis entrevistados. Houve uma grande flexibilidade de escolha das pessoas, mas curiosamente depois das primeiras entrevistas as demais foram sendo feitas a partir de indicações, revelando relações entre os entrevistados (fato a ser pormenorizado no próximo item). Com isso, a metodologia de pesquisa ganhou a naturalidade

\footnotetext{
${ }^{34}$ Evento nascido na Espanha, em 1997, é considerado o maior evento de inovação, ciência, criatividade e entretenimento digital do mundo. Acontece também no Brasil anualmente. Em 2011, foi realizada sua quarta edição. Ver http://www.campus-party.com.br/.
} 
do encontro ao acaso, o que exigiu do entrevistador alguma capacidade de adaptação uma vez que fugia das copiosas recomendações em livros sobre entrevistas em pesquisas qualitativas e, sobretudo, se afastava das notórias colocações de Bosi (2003, p. 60) quanto ao tipo e a qualidade do relacionamento estabelecido:

a entrevista ideal é aquela que permite a formação de laços de amizade; tenhamos sempre na lembrança que a relação não deveria ser efêmera. Ela envolve responsabilidade pelo outro e deve durar quanto dura uma amizade.

Noutro momento, nessa mesma obra, a autora traz um elemento profundamente relacionado com nossa pesquisa. Em suas palavras: "Da qualidade do vínculo vai depender a qualidade da entrevista." Essa breve e valiosa frase já assinala aqui a importância da relação, do vínculo e do investimento em um objetivo conjunto.

\subsection{O trabalho de campo e as entrevistas}

Seguindo algumas diretrizes do trabalho de orientação, foi feito um estudo-piloto para melhor delinear um roteiro de perguntas e para que houvesse uma adaptação pela experimentação com o procedimento de entrevista. Essa 
etapa do trabalho foi valiosa e permitiu melhor visibilidade e contato com os procedimentos de pesquisa.

As entrevistas foram finalmente realizadas nos entre os dias 19 e 21 de janeiro de 2011, durante o evento Campus Party Brasil IV, ocorrido no centro de exposições Imigrantes. O ingresso ao evento foi feito com alguma insistência mediante credenciamento prévio na categoria "Imprensa", já que a de pesquisador não é contemplada.

Foram entrevistados dez participantes do evento, de ambos os gêneros e diferentes faixas etárias, variando de 21 a 54 anos. Suas maneiras de se relacionar com a temática das TICs também era muito variada, contemplando usuários recreativos, blogueiros, profissionais de diversas áreas ligadas à tecnologia e internet, técnicos e acadêmicos. As entrevistas totalizaram 294 minutos de gravação, que originaram 130 páginas de transcrição. O preparo prévio para as perguntas, tanto em termos da técnica de entrevista quanto em relação aos conteúdos relacionado, potencializou o estabelecimento de uma relação empática durante as conversas, o que foi determinante para que houvesse condições de se discutir e explorar fluidamente tanto as temáticas de interesse como outros assuntos emergentes, relacionados e igualmente interessantes. Entretanto, isso acarretou grande volume de material de modo que as transcrições constantes no anexo foram redimensionadas para destacar o conteúdo mais expressivo dos temas aqui discutidos. 
No primeiro dia do evento, nenhum dos possíveis entrevistados compareceu ou estava disponível, de modo que houve tempo para a ambientação com o local e sua dinâmica. Essencialmente, o Campus Party Brazil é uma grande área coberta, rodeada por palcos nos quais são apresentadas as palestras sobre inovação, ciência e tecnologia. No meio dessa área, estão distribuídas organizadamente extensas mesas com pontos de acesso à internet nos quais os campuseiros (como são chamados os participantes do evento) conectam seus computadores.

O primeiro entrevistado, Alex, foi encontrado fortuitamente enquanto o entrevistador interagia com um dos dispositivos tecnológicos ali disponíveis para experimentação do público. A entrevista, que se deu no espaço reservado para a imprensa, atraiu a atenção de um grupo de pessoas que faziam a cobertura do evento, e a segunda entrevistada, Bia, e o terceiro, Carlos, vieram espontaneamente desse grupo (foi concedido ao terceiro entrevistado uma entrevista a respeito desta pesquisa). Durante esse dia, o pesquisador teve a oportunidade de conhecer algumas pessoas, dentre elas a quarta entrevistada, Diana, uma das pioneiras na blogsfera brasileira, com grande visibilidade no mundo virtual. Ao conceder a entrevista, Diana foi interrompida por um amigo, Ernesto, e ela sugeriu que este também fosse entrevistado. Ele concordou. Acabada a entrevista com a quarta entrevistada, Ernesto rapidamente se organizou para conceder sua entrevista. A sexta participante, Fabiana, surgiu durante a preparação pra entrevista de Ernesto, é sua amiga e ela mesma se 
interessou em ser entrevistada. A sétima entrevistada, Giovana, por sua vez, é amiga de Fabiana. E a oitava, Helen, havia sido indicada por Diana. Somente a nona participante, Ingrid, e o décimo, João, foram selecionados separadamente, dado o destaque e exclusividade com que essas pessoas se envolvem com as temáticas deste trabalho. 


\section{Análise e discussão dos dados}

6.1. Primeiras impressões sobre a coleta de dados

Uma das principais motivações para a adoção das entrevistas foi a necessidade de confrontar os controvertidos posicionamentos a respeito do uso e das consequências das TICs com dados da realidade. De um lado, a crítica negativa de intelectuais consagrados internacionalmente com uma vasta produção teórica. De outro, diversos e novos estudos de nomes menos proeminentes, mas altamente engajados, ou vozes solitárias em defesa das novas tecnologias e um convite para um olhar reconfigurado das potencialidades de seu uso.

As entrevistas foram realizadas com consciência de um exercício científico necessário de imersão em condições objetivas, indo da teoria ao objeto, ainda nebuloso, e retornando à teoria e ao objeto dialeticamente. Era sabido de antemão que o público presente no evento, onde se deram as entrevistas, possuía bom nível de escolaridade, era envolvido e interessado de alguma maneira com a temática tecnológica. Propositadamente foram entrevistadas pessoas de diversas faixas etárias de ambos gêneros e com múltiplos modos de se relacionar com as TICs. 
A primeira constatação, já visível na bibliografia defensora do uso das TICs, evidenciou-se consistentemente: a dos benefícios da tecnologia, refletida sobretudo, no uso das redes e das diversas maneiras conjugadas (ou não) de comunicação mediada pelas tecnologias. Por outro lado, a presença da crítica com relação às limitações dessas mesmas tecnologias esteve igualmente presente e com grande vivacidade nos relatos.

"Se os humanos quiserem se encontrar. Quer dizer, potencializar o desejo do humano, né. Eu diria, né, eu acho mais preciso. Porque se o ser humano que usar a tecnologia quer encontrar ele vai encontrar, se ele quer esconder, ele vai esconder." (Diana)

"A essência é a mesma, então nós temos o mesmo fenômeno, que são pessoas que precisam se organizar para algum fim determinado e vão procurar os meios mais interessantes pra isso. Internet, no começo foi o telefone e assim teria sido a carta ou as assembleias, mas uma das possibilidades que a internet dá, na verdade que os meios digitais dão, é primeiro você ter a liberdade em relação ao espaço e ao tempo, porque você continua uma discussão mesmo que não estejam todos presentes ao mesmo tempo, cria uma discussão mesmo que estejam todos distantes. Então a esfera da discussão, ela se liberta destas limitações da presencialidade ao mesmo tempo que você tem uma relação de intimidade muito menor. Então por mais que você se esforce em divulgar, sabe, fotos do seu filho do seu dia dia, a música que você gosta, mas com esta troca de intimidade, a intimidade imediata né, que é a que acontece entre os indivíduos, ela não tem o mesmo espaço pra acontecer à distância em tempos diferentes. Então os laços são diferentes, os interesses, eu acho, que são os mesmos; eles sobrevivem às condições 
midiáticas. Se trocasse de mídia, de internet, por alguma outra mídia diferente, os interesses continuariam lá presentes se organizando da melhor maneira que eles pudessem se organizar." (Alex)

"A vantagem é que você consegue falar com as pessoas a qualquer momento. Com seus amigos ou inimigos, e falar com os inimigos é ainda melhor porque ele não está perto. A parte ruim é a falta de contato humano com as pessoas como era antigamente, com o meu pai, quando ele tinha que ir até a pessoa e olhar olho no olho. Não existe tanto isso hoje em dia." (Ernesto)

"Tenho Twitter. É uma rede assim bem interessante de usar né, porque ao mesmo tempo que você tá conectado com meio mundo, você não tem ninguém. Então fica aquele dilema né, proporcional, seria né ao mesmo tempo que você tá com todo mundo, conversando com o mundo inteiro - gente da Espanha de Portugal você tá em casa, sem contato nenhum, com até família, com seus familiares, seu irmão... você acaba esquecendo um pouco o que você tem dentro de casa e querendo conhecer o mundo, conhecer o mundo entre aspas, porque você fala sozinho literalmente falando. $E$ aí é muito interessante, eu particularmente gosto, eu uso. Assim dá pra expor minhas ideias, trocar ideia com todo mundo e passar o tempo, né?" (Bia)

A ambiguidade na relação com as TICs que fora descrita de diferentes maneiras na bibliografia também nos permite interessantes considerações, mais pormenorizadas, nos próximos itens deste trabalho.

Surgiram nas entrevistas alguns dados interessantes em relação ao modo e duração de uso das TICs. Se estar conectado é estar presente e disponível 
"em potência", como descreve Lévy, era de se esperar, e de fato os entrevistados se mantêm, o quanto puderem conectados à internet.

Interessante comparação pode ser feita com a célebre frase de Marshall McLuhan. Se para o filósofo o meio é a mensagem, e no nosso panorama a "permanência" conectada é tão duradoura quanto possível, suas teses estão perfeitamente corroboradas pelas constatações desta pesquisa. Não obstante, se em sua época o pensador buscava comprovar a extensão tecnocrática e ideológica dos meios de comunicação no homem, nos dias de hoje não haveria dificuldade alguma de comprovar suas teses. Estendendo o entendimento de que os meios são causa e motivo das estruturas sociais, podemos compreender que até mesmo aqueles alheios às TICs são também por elas profundamente afetados.

"Olha, me sinto afetada por completo. Tem dias que você fica a ponto... estressado. Você começa a ficar muito agitado. Eu tenho feito atualmente um trabalho e... inclusive monitorar meu tempo em relações a estas ferramentas. E já que eu tenho uns relacionamentos que me facilitam o processo, e eu tenho uma sócia que trabalha comigo pra... no caso, nesta questão de mídias sociais pra empresa. Porque você chega no final do dia, você sai extremamente ligado, você tá agitado, né. Porque a velocidade de informação é tanta e você, às vezes, chega a ponto de você começar a ter falha de memória. É como um copo que você vai enchendo, enchendo, enchendo... as coisas vão transbordando. Entra uma coisa mas tá saindo outra. Você... é muito informação. Você tem que começar a filtrar. O que serve pra você e o que não serve. Até onde eu vou com 
o meu estudo, né. Ainda tem isso. Porque se toda hora eu entrar em todas as ferramentas eu vou ficar louca. Então eu tenho que começar a filtrar [...] Eu já estava pensando em 140 caracteres. Isto foi a parte que eu me senti afe[?], eu via um negócio na rua... eu pensava ligar pra um amigo pra comentar ou chegar em casa, porque eu divido apartamento com amigos, chegar em casa pra comentar... eu já pensava assim... em 140 caracteres... é... [risos]... pra eu rir. Eu falava pra pessoa... sei lá... eu ri... é... eu falava pra pessoa pá, pá, pá, pá... eu ri... ou então, $k, k, k, k$, $k$. Eu já comecei a falar essa lin... eu falei: NÃO! PARA! Para que agora você está enlouquecendo. Pode parar porque aí já chegou o limite, né... E eu tava muito acelerada. Eu sou geminiana, já falo rápido, acelerado, então não tava dando certo, né. Você fica agitada a ponto de perder o sono mesmo, quando você vê já são 4 horas e você está na internet ainda, sabe... pra acordar às 6 no dia seguinte." (Helen)

"Eu não desconecto, né. Eu tenho "mobile". Não desconecto nunca. Se perguntar pra mim quantas horas estou conectada... Tô acordada, tô conectada. "Popa" mensagem aqui do Facebook, "popa" mensagem do Twitter, "popa" quando alguém me cita no Twitter, "popa" quando recebo e-mail, o celular vive "popando", então tô sempre conectada." (Fabiana)

"Sim, quando eu falo "a gente" eu me incluo. Eu sou viciada. Sou daquelas que se eu for pro sítio que não tem internet eu fico angustiada assim. Não porque eu preciso, assim... é por uma forma de passar o tempo. Também eu acho que é essencial você ter conhecimento, ter alguma coisa pra fazer, sempre interagir, trocar informação. Eu acho que se você tem conhecimento e não pode conversar, não pode trocar, acho que conhecimento é em vão. Então as redes sociais de internet estão aí pra isso, né, pra trocar 
conhecimento, pra saber da vida do outro, tanto pra fofocar, pra falar bem, pra apoiar, até pra motivar. E eu consigo... eu não consigo sair da internet... assim eu posso, sei lá, andar, mas eu prefiro ficar na frente do computador. É melhor é mais confortável e é isso né." (Bia)

Marilena Chauí faz um breve comentário sobre a relação entre a dimensão econômica e a percepção de espaço e tempo que se alia de modo interessante ao entendimento dos relatos acima:

\begin{abstract}
A dimensão econômica e social da nova forma do capital é inseparável de uma transformação sem precedentes nas experiência do espaço e do tempo, designada por David Harvey como a "compressão espaço-temporal". A fragmentação e a globalização da produção econômica engendram dois fenômenos contrários e simultâneos: de um lado, a fragmentação e a dispersão espacial e temporal e, de outro, sob os efeitos das tecnologias eletrônicas e de informação, a compressão do espaço [...] em outras palavras, a fragmentação e a dispersão do espaço e do tempo condicionam sua reunificação sob um espaço indiferenciado (um espaço plano de imagens fugazes) e um tempo efêmero desprovido de profundidade." (Chauí , 2006)
\end{abstract}

\title{
6.2. As redes e as novas formas de vinculação
}

Um dos dados mais notórios oriundos das entrevistas foi a massiva quantidade de relatos contendo experiências positivas e construtivas em se tratando de relacionamentos mediados pelas TICs. Essas informações apontam 
para uma efetiva constituição interacional mediada. Apesar de descrito pela literatura, a notoriedade foi de que a totalidade dos entrevistados não somente relatou experiências significativas mediadas pelas tecnologias, como também argumentaram, com conhecimento de causa, a defesa e o futuro promissor das relações mediadas.

"Eu vejo uma vantagem clara em poder compartilhar [pela internet] minha experiência apesar da distância com outras pessoas." (Alex)

"Às vezes você perde... por exemplo... a oportunidade de saber que aquele jeito que a pessoa tá falando... se você [a] encontrar... ela falasse a mesma coisa pra você pessoalmente, você ia ver que ela tá falando com um tom de voz irônico ou com um olhar diferente que você ia sacar na hora que aquilo não é assim. Mas lendo, você não consegue saber. Você perde realmente o visual assim, você conseguir ouvir, ver a pessoa, o tato assim. É uma coisa que pode atrapalhar pra caramba de você não ter. Eu tive um outro namorado que eu falava pra ele... a gente começava a discutir então ele sempre conseguia discutir por e-mail e quando eu descia, saia do computador, ia batia na porta da casa dele, ele não conseguia falar igual. Só que eu achava isso ruim porque às vezes na internet, por email, ele conseguia falar coisas que ele não ia ter coragem pra me falar pessoalmente. $E$ se ele não tem coragem de me falar pessoalmente de repente não é o que ele tem que me falar. Sabe, eu sempre pensava muito isso. Porque é muito fácil você se defender atrás de uma tela de computador quando ninguém está olhando para a sua cara." (Giovana)

"O que muda aí, eu acho, é simplesmente o meio por onde se chega à coisa. Se você cresce numa rua, tem amigos desde a infância, tudo bem, são seus amigos. De repente, você conhece uma pessoa na 
internet e, em quatro meses, essa pessoa é tão amiga sua quanto alguém de infância. 'Ah, mas a internet é perigosa, a gente tem que ficar esperto, né.' Na vida real também é assim. Então, às vezes, eu acho que cai por terra aquele lance das pessoas falarem que 'Ah, você arrumou uma namorada, uma esposa na internet'. É possível, é possível. É, mas na internet você não sabe se essa pessoa é gente boa. Se você for sair para uma balada, for pra uma festa, enfim se alguém te apresentar um amigo, alguém apresentar: 'Olha, essa aqui é minha amiga e tá querendo te conhecer." Dependente... essa amiga não é a pessoa que você estava imaginando. Então, eu acho que só muda o meio aí. Ou via internet ou pessoalmente. Via internet talvez seja mais rápido, você chega em lugares onde você não chegaria... Você pode conhecer pessoas de outros estados, outras cidades, países. Pessoalmente, bom, beleza, quero conhecer alguém de Salvador. Então você vai pegar um avião, vai pra Salvador e dá uma volta por lá. É um pouquinho mais complicado. Aqui, nesta conversa, eu posso conhecer alguém, enquanto estou falando com você, no MSN, que esteja em qualquer canto do mundo. Então, acho que só muda isso." (Carlos)

"No projeto que eu trabalho da cidade de São Paulo, existe a 'Rede de Projetos', que é um cluster por onde os pontos... os inconscientes se encontram. O pilar dela é um site, um grupo, que as pessoas documentam os projetos. Então, raramente essas pessoas se encontram, mas o dia a dia é produção neste site. Blog, fórum e hiperdiscussão... E aí eles, por conta própria, criam muitas comunidades com referência nos projetos. Porque os projetos podem ser desde artesanato e... mas eles envolvem tecnologia. Então, a pessoa pode usar o InfoCentro que ela trabalha para desenvolver um projeto de artesanato. Mas em algum momento ela tem que documentar isso e criar um blog e colocar este artesanato on-line. Então a tecnologia não fica meio empecilho pro cara. O cara não tem que aprender tecnologia, mas tem que usar como alavanca pra ideia 
dele. E o site 'Rede de Projetos' é um cluster pra galera trocar informações, trocar figurinha, mas não fica preso também a este site, é só um ponto de encontro. Muitos projetos são desenvolvidos via Orkut, Facebook, e tem muitos projetistas que usam o Twitter pra divulgar os projetos, né. Fora a galera que é mais iniciada do Metareciclagem, isto já é de praxe." (João)

Os dados concordam com as constatações de Nicolaci-da-Costa (2005), quando afirma que as severas críticas às TICs oriundas de teóricos do porte de Zygmunt Bauman (extensível a outros teóricos tais como Richard Sennet ${ }^{35}$, Gilles Lipovetsky e Anthony Giddens que também constroem suas argumentações a partir de pressupostos históricos), carecem de fundamentação empírica com consequências. A autora cita o extenso estudo de Castels $^{36}$, que no volume $A$ sociedade em rede, de sua obra $A$ era da informação: economia, sociedade e cultura, faz um notável relato sobre a maneira como os intelectuais europeus se colocaram frente às possíveis mudanças advindas das TICs (na época nem tinham essa denominação), em especial à internet nos anos de

\footnotetext{
${ }^{35}$ Muito embora este autor tenha se utilizado de dados estatísticos em $A$ corrosão do caráter, 2007.

${ }^{36}$ CASTELLS, Manuel. A galáxia da internet: reflexões sobre a internet, os negócios e a sociedade. $1^{\underline{a}}$ ed. Rio de Janeiro: Jorge Zahar, 2003.

"A sociedade em rede". Em A era da informação: economia, sociedade e cultura. $4^{\underline{a}}$ ed. São Paulo: Paz e Terra, 2000.
} 
1995-1997. Essa postura defensiva e negativista adotada desde então tem ofuscado a real apreensão das possibilidades e limitações dessas tecnologias.

Nicolaci-da-Costa ressalta alguns aspectos que são comuns aos críticos das TICs que podem gerar interessantes questionamentos. Este trabalho concorda com a autora quanto a sua preocupação em relação à atualidade dos acontecimentos diante da velocidade da publicação. A maior parte das críticas advindas desses intelectuais formadores de opinião é baseada em panoramas das relações do homem com a tecnologia que mudam rapidamente e que, embora não deixem de ser válidas, possam ser um registro histórico e conter prognósticos desse cenário, estão fadadas a um descompasso entre a atualidade dos fatos e as ideias constantes nas publicações. Outro aspecto interessante é a de que a maior parte dos teóricos generaliza a crítica negativa contra as tecnologias. Acreditamos que, em grande medida, isso seja devido ao modo como um sociólogo analisa a sociedade, pautado principalmente nos efeitos macroscópicos e no desenvolvimento dos processos entre os agentes ao longo do tempo. Somado a isso o desconhecimento e a falta de distinção entre as diferentes capacidades e características das diversas formas como a tecnologia hoje se coloca à serviço do homem.

Nicolaci-da-Costa ainda postula que autores do porte de Bauman em grande medida negligenciam a ampla literatura existente sobre relacionamentos virtuais mediados por diferentes tecnologias. Segundo a autora, no Brasil, tais impactos seriam ainda mais danosos tendo em vista a diminuta produção 
científica relativa ao tema, da constante importação de dados de intelectuais estrangeiros e da supervalorização de seus autores cujas ideias assumem status de verdade incontestável.

Valiosos comentários sobre essa mesma questão são levantados por Gomes $^{37}$ (2010) que estudou as implicações políticas das relações de amizade mediadas pela internet. Nessa obra, a autora complementa as críticas oriundas de diversos artigos de Nicolaci-da-Costa com o posicionamento de autores como Manuel Castels, Dominique Wolton e Pierre Lévy. Uma das constatações levantadas é a de que as críticas se baseiam nas tecnologias do início da difusão da internet e de seu desenvolvimento.

Importante ressaltar que um dos argumentos de Nicolaci-da-Costa contra a produção científica de Bauman seria a falta de fundamentação empírica que colocasse à prova suas ideias. Conforme explora Gomes (2010), grande parte dessas colocações se devem ao debatido e controverso modo sui generis como Bauman constrói suas argumentações e expressa suas elocubrações.

Embora as observações de Nicolaci-da-Costa (2005) em relação a Bauman tenham sido bem colocadas e concordemos com os descompassos apontados, é sabido que o sociólogo e filósofo não é afeito a análises numéricas estatísticas. De certo modo, essa qualidade de análise é incompatível com um

37 Gomes, L. G. N. Implicações políticas das relações de amizade mediadas pela internet 2010. 264 p. Tese de doutorado. Instituto de Psicologia, Universidade de São Paulo, São Paulo, 2010. 
intelectual admitido como expoente da sociologia humanística. Se em algum momento faltaram estatísticas, isso se deveu não a um traço estilístico ou simples negligência, mas sim a uma edificada orientação cuja metodologia científica se pauta em outras bases e a partir de outros pressupostos, cujas influências remontam a pensadores como Georg Simmel, Emmanuel Levinas Jacques Derrida, e profundamente alinhado com o pensamento crítico de autores tais como Antonio Gramsci, Hannah Arendt, Theodor W. Adorno, Erich Fromm e também outros comumente debatidos por Bauman, que são referidos neste trabalho, dentre eles, Alan Touraine, Anthony Guiddens e Manuel Castels.

Embora os dados colhidos nas entrevistas apontem para um cenário bem diferente do cataclismo líquido de Bauman, e as considerações de Nicolaci-daCosta (2005) - as quais, reiterando, concordamos - se confirmem novamente nesta pesquisa, as entrevistas trouxeram também um considerável volume de críticas e dificuldades relativas aos usos e a presença massiva das tecnologias mediadoras de relações, com destaque para as relações mediadas pela internet. Essas críticas não vieram, entretanto acompanhadas de reflexões sobre essas problemáticas ou seus processos e consequências, o que nos leva a crer que algumas características levantadas pelos intelectuais críticos às TICs - tais como a passividade, o isolamento e o desamparo podem estar relacionadas à crise da experiência não mediada, com a flexibilização dos referenciais espaçotemporais, as diversas descontinuidades vividas (porém não pensadas) 
advindas da perda de um historicismo ${ }^{38}$. Nesse ínterim, as teses de Bauman e de outros intelectuais críticos da pós-modernidade e das TICs não podem ser invalidadas.

Resumidamente, acreditamos que as constatações de Bauman e de outros teóricos da mesma estirpe podem estar exageradas e generalizadas, mas fazem sentido e se destacam por tecerem um entendimento macroscópico e uma contextualização dos indivíduos no mundo, não devendo portanto ser menosprezadas. Gomes (2010) também adota essa posição utilizando extensivamente autores críticos à pós-modernidade e às TICs. Por exemplo, ao analisar a crítica de Wolton e Sennet em relação à maneira aleivosa pela qual os ideais individualistas liberais se dissimulam com consequências:

Wolton (2003) ressalta que as características de autonomia, domínio e velocidade, inerentes à internet correspondem ao cerne do ideal individualista liberal. A performance pautada na autonomia e ausência de controle, na possibilidade de escrever, apagar, arquivar, corresponder-se e comunicar-se em tempo real, são atrativos sedutores na cultura contemporânea de valorização da liberdade individual, o que faz com que a web alimente nefastas ilusões de uma sociedade na qual os homens podem se emancipar individualmente. A ligação social nasce do senso de mútua dependência. Wolton (2003) e Sennett (1999) chamam atenção para o fato de que os imperativos neoliberais ao valorizarem a autonomia

\footnotetext{
38 Tomamos como referência o historicismo dialético de Hegel e Marx sem nos deter nas particularidades de cada uma dessas concepções, focando nossa atenção no caráter contínuo que constitui um nexo existencial para a emancipação do homem.
} 
têm produzido o sentimento de dependência como uma condição vergonhosa. (Gomes, 2010, p. 39)

Noutra passagem, analisando as ideias de Bourdieu:

A atual estratégia insidiosa do mercado na tentativa de captura do consumidor tem sido a utilização de uma estrutura discursiva que associa a aquisição de objetos de consumo como condição necessária a uma vida afetiva satisfatória e a plena satisfação dos desejos. A lógica contemporânea de consumo privilegia e valoriza a "dimensão imaterial" do produto que será consumido. Mais do que o produto em si mesmo, o que se vende hoje é a dimensão da imaterialidade que é associada a este, ou seja, é a qualidade imaterial dos afetos, perceptos, sensações, sentimentos, etc. os quais são articulados aos produtos que é posta à venda - processo que se liga ao advento da sutilização inédita das modalidades de controle social, advertido por Bourdieu (1998). (Gomes, 2010, p. 43)

Devemos lembrar que Pierre Lévy, o intelectual mais proeminente na defesa dos benefícios das TICs, também não faz préstimo de dados numéricos ou estatísticos. Encontramos destacadamente em Egler ${ }^{39}$ (2007) uma consistente articulação das potencialidades das redes com diversos estudos estatísticos e mapeamentos em sua pesquisa sobre as redes sociotécnicas, políticas públicas e gestão democrática das cidades (assunto que será discutido no próximo item).

${ }^{39}$ EGLER, Tâmara Tânia (org.). Ciberpólis: redes no governo da cidade. Rio de Janeiro: 7 Letras, 2007. 
Retomando o destaque de um dos principais conteúdos das narrativas, a expressiva percepção positiva e construtiva das relações estabelecidas ou possíveis através das redes virtuais, a maior parte dos entrevistados citou fóruns de discussão, lista de grupos de e-mails, diversas redes sociotécnicas e o Twitter. Ao que parece, a possibilidade gregária presentes nessas redes seria capaz de estabelecer alguns tipos de relação e laços diferentes daqueles forjados fora do ambiente mediado, mas que poderiam levar a relacionamentos sem mediação.

“[...] a história começou em 2007, eu produzi um 'BlogCamp' depois de ir a um 'BarCamp', descobri o que era o conceito de "BarCamp" de espaço aberto e eu me apaixonei porque são eventos criados pelos próprios participantes. Não tem uma grade de programação, o participante cria a programação dele. Ai eu fiz o 'BlogCamp' que é só pra blogueiro... fiz dois, em 2007 e 2008, conheci muita gente de internet, de Intercom, etc... participei do lançamento da "CampusParty" no Brasil. Em 2008, eu olhei e "meu, porque que as mulheres não aparecem?". Tem muita mulher na rede e as mulheres não estavam aparecendo nos eventos. Aí, eu falei: 'meu, vou fazer um evento só de mulher, um Camp só de mulher' [...] Falei: 'ó vamos fazer'...

"Juntei os amigos, consultei... meu bacana.. faz... já tinha espaço. Falei: ah... vamos fazer. Construí o blog...fiz a votação... a gente fez... no nome foi escolhido coletivamente, né, meio no Twitter, meio no blog tal, teve um monte de conversa já, porque a gente já tava no Twitter em 2007, 2008, né. E a gente escolheu o nome [...] uma das meninas do grupo fez o logotipo pra mim,... então assim... tem o logotipo do nacional e cada regional tem o seu logotipo, porque 
também surgiu esta questão na comunidade, quer dizer, ah... eu não posso ir pra São Paulo, como é que eu faço? A gente fala: 'faz aí, pô'. Junta uma mulherada e conversa, né... quer dizer. E aí a gente montou um 'modelão' de como se faz, que é um modelo colaborativo, você tem uma líder, uma liderança que organiza, fecha negócio, fecha contrato tal, coordena, né, coordenação... E eu meio coordeno todas as coordenadoras, né [riso]. Não tem muita estrutura, mas a gente já tá hoje em 8 cidades. [...] E é uma paixão assim... As mulheres adoram!... adoram!... é muito gostoso... [...] Como as conversas são definidas pelas participantes, é desde ecologia, proteção animal, lixo eletrônico... a gente faz bazar de troca. Todo mundo leva comida e, às vezes, tem de troca de refeição. 'Ah... como você faz isso, como você não faz'. Tem comida até. Tem conversa sobre feminismo, movimento feminista, política." (Diana)

"Algo negativo, eu acho que existe. Não é tanto uma negatividade do fenômeno internet em si, mas é porque existe um desejo de realizar essa interação com as pessoas. Gente que você conheceu em trocas pela internet ou que você gostaria de conhecer pessoalmente e que não é economicamente viável. Não é fácil de você ir pro Peru ou de você ir pra Índia e experienciar, sei lá... um dia de família ou um dia de realmente trocas físicas com outras pessoas. Embora a gente acabe procurando isso, trocando fotos, trocando confidências, blogs, intimidades de Twitter, Facebook... essas coisas. Neste sentido, eu vejo que as redes sociais em geral servem pra amenizar esta distância de não poder fazer esta troca efetiva. Mas ao mesmo tempo ela está sempre chamando pra fazer esta troca efetiva. $E$ que ela vai acontecer em espaços que nem aqui, na campus party, que nem nos encontros de software livre ou encontros de comunidades pelo mundo, sabe? Ah, minha esposa tem uma experiência bem extensa com redes de maternidade ativa de mães que se dedicam a 
discutir né as experiências de mãe. E aí vai a questão do uso de fraldas de pano, de discutir a respeito de vacinação e tudo mais. $E$ toda esta experiência, né, de troca simbólica e tal se materializa em eventos, vamos dizer assim trimestrais. Alguém se encontra com um na casa de fulano numa cidade do estado de São Paulo, e aí vêm várias pessoas do país e tal pra um lugar. Então, não é uma coisa exclusiva da comunidade do software livre. [...] são diversos exemplos de redes que se organizam pela internet mas que tem como finalidade uma troca material tipo, imediata, sabe? Realizada realmente entre pessoas compartilhando um espaço físico." (Alex)

Fica claro no discurso de Alex que ele está parcialmente consciente das limitações das relações mediadas e de que as ferramentas, que a medição dispõe, não são capazes de suprir o real ensejo que se espera suprir em encontros efetivos compartilhando um espaço físico. Cabe aqui a indagação de que talvez Alex não tenha ciência de que o que ele e outros internautas buscam além das relações mediadas com tanta veemência é justamente o elemento vivencial, a experiência do ser integral, das trocas intersubjetivas, que só pode se dar na presencialidade, no encontro com a alteridade. Não pode se dar pela mediação. Os relatos apontam para aquilo que Lévy, de modo mais retumbante e utópico, e muitos outros defensores das vantagens e potencialidades das TICs, destacam: a natureza social e relacional do homem se utiliza das ferramentas disponíveis para tecer sua narrativa histórica, construir sua realidade e, nesse contexto, existir. 
Os entrevistados utilizaram das redes sociotécnicas e diversos outros recursos mediados para estabelecer comunicação e formar contatos, relações, laços e vínculos com uma qualidade aparentemente diferente daquelas que a psicologia está habituada a lidar. Essas relações potencializaram encontros reais, trocas simbólicas intersubjetivas imediatas e, ao que tudo indica, possivelmente duradouras. Nesse sentido, é preciso repensar a crítica aos sistemas em redes digitais, ao uso das TICs nos relacionamentos e sobretudo repensar o novo conceito de vínculo mediado. Teria ele qualidades tão distintas a ponto de merecer outra nomenclatura ou seria apenas uma flexão do conceito original a partir de outros contextos e demandas?

As entrevistas apontam para uma espécie de vínculo mediado com uma intensidade afetiva. Talvez os vínculos afetivos estabelecidos pela internet sejam de fato sentidos como profundamente reais, e que realmente afetem e sensibilizem o indivíduo. No entanto, se assim for, precisamos repensar o conceito de o que seria uma experiência integral ou completa. Se essas novas formas mediadas de experiência são descritas como válidas e proveitosas, seria interessante saber sobre quais bases e de que modo as narrativas pessoais e a historiografia está se constituindo, tendo em vista que a velocidade dos desenvolvimentos tecnológicos são em grande parte ditados por interesses econômicos. Noutra passagem da entrevista, Alex diz:

"Então, eu considero todas as trocas reais. Efetivamente eu tô fazendo uma troca, eu tô compartilhando alguma coisa dizendo 'olha 
aconteceu isso comigo ontem. Eu tava lá.' 'Olha comigo também.' $E$ a gente lida e tal. É uma coisa real, mas a mediação tem uma coisa entre a gente. Talvez seja meio clichê o termo, mas tem uma coisa entre a gente que cria a comunicação, então por mais que eu tenha uma habilidade literária em expressar, sei lá, coisa e tal um choro ou uma reclamação chega na outra pessoa na forma de palavra dura no computador. Ela não tem a mesma característica imediata para ver a pessoa na sua frente, a comunicação... ela se dá essencialmente de forma verbal."

O entrevistado aponta para uma limitação dos vínculos através da mediação. Ele está consciente dessa limitação e, por suas redes, ele procura articular encontros reais, físicos, como ele mesmo descreveu no meatspace, lugar onde as trocas intersubjetivas podem acontecer de maneira mais satisfatória sem a intermediação. Essas constatações se harmonizam com algumas das constatações de Bauman (2004) a respeito do desamparo dos indivíduos na modernidade líquida, sem contornos, com as instâncias e instituições tradicionalmente doadoras de referencias e constituidoras do tecido social, sendo colocadas em xeque e substituídas pelas conexões em rede. Nesse sentido, vemos um cenário muito delicado e temerário para a constituição de vínculos duradouros com a marca da historiografia. Se a lógica de redes pressupõe fácil conexão e, na mesma medida, desconexão, como ficariam os laços? Alex fala de um exemplo profissional: 
"Pela internet é a interação que está em primeiro lugar. Então se eu estou tratando com uma pessoa que não está disposta a colaborar com alguma coisa, eu não tenho motivo pra continuar a interação justamente porque eu tenho um volume muito grande de outras pessoas com quem eu posso ter essa mesma interação dentro daquele mesmo escopo. Se eu estava procurando alguém que me ajudasse a desenvolver tal coisa e esse alguém que eu encontrei foi, teve, uma experiência ruim... ou nós, não consegui colaborar com ele e tal, pula pro próximo, sabe? Inclusive não tem é... mágoas. Entendeu? Tipo, 'ah, tentou, não deu, bola pra frente', sabe?’

Numa primeira leitura, o desenvolvimento do aparato tecnológico que permite a criação e manutenção dessas redes tem sido determinante para que mais pessoas possam contribuir para os conteúdos da rede.

Cabe agora uma breve explicação sobre os desenvolvimentos lógicos da própria internet. Um dos termos que se tem utilizado comumente para descrever os desenvolvimentos da internet em suas mudanças na concepção de uso, não na sua estrutura tecnológica ficou conhecido como Web 2.0. As mudanças aconteceram no modo como os conteúdos passaram a ser produzidos e organizados. Um dos conceitos da Web 2.0 é a folksonomia, termo criado por Thomas Vander Wal que antecede o surgimento da internet e que se refere ao modo como os homens (folks) indexam e organizam suas informações a partir de escolhas pessoais marcadores (tags), ou palavras-chave.

O conceito "wiki", do havaiano "Wiki-Wiki" (extremamente rápido), também se refere à formação de conteúdo colaborativo. A partir dessas 
mudanças lógicas de concepção, criação, difusão e organização da informação permitiu-se toda uma reconfiguração da maneira de lidar com a informação. Os usuários passaram a ser não somente consumidores de dados, mas também colaboradores e principalmente emissores de conteúdos. Nas palavras de Giovana: "a maior coisa assim... o mais legal... e talvez o mais complicado de lidar é o fato de todo mundo ser emissor agora. Acho que isto é o mais importante."

Um aspecto interessante levantado nesse trecho é que uma vez que todos são emissores, a rede poderia ficar inundada com conteúdos pouco estruturados e baseados em opiniões pessoais ou repetições distorcidas de conteúdos e ideias. O que não deixa de ser verdade. Há uma vastidão de inutilidades, mas uma das características interessantes dos conteúdos colaborativos é a capacidade de cruzar informações desde que elas estejam devidamente indexadas. Com isso, é possível filtrar as informações mais acessadas, mais relevantes ou mais distribuídas, cabendo ao usuário avaliar a real consistência dessas referências e, se lhe convier, referenciá-las pelos canais que Ihe interessem. É nesse contexto que Dominique Wolton defende a importância formativa da educação, dos livros e do jornalismo crítico frente ao volume de dados desorganizados. O autor é o contraponto diante da febre com que se alardeiam as novas mídias. É irredutível ao afirmar as limitações e os perigos dos conteúdos disponibilizados na internet. Em suas palavras: "O problema da sociedade da informação é a liberdade de perversão da 
informação. Temos que perceber que nem tudo pode ser informação. A sociedade da informação é um mito de racionalização." Nesse sentido, o autor não está se referindo somente aos dados inúteis constantes na rede, mas principalmente à sistemática mercantil com que os conteúdos são difundidos nela e que regem a própria estrutura da internet. Com isso, critica abertamente a noção orgânica e homeostática da rede, bem como todas as analogias presentes nela como um rizoma, ou como a formação neuronal, como formas naturalizantes da tecnocracia. Gomes (2010) ao comentar a naturalização destaca as considerações de Musso:

\begin{abstract}
Musso (2003) sugere que o discurso contemporâneo de rede é marcado por seis características da operação simbólica saintsimoniana sobre a idéia e a imagem de rede. A primeira delas, destacada por Musso (2003) como a mais potente e mais antiga, é qualificada como biotecnológica, já que se funda na analogia entre rede e o corpo, em particular entre o cérebro e a rede. $\mathrm{O}$ autor afirma que tal modelo do organismo-rede permite naturalizar a nova técnica, visto que a torna "calorosa", além de ajudar sua inserção social, apresentando-a como uma necessidade para renovar o corpo social.
\end{abstract}

Outro dado interessante advindo das entrevistas foi a mudança qualitativa de relacionamentos familiares, não mediados, quando a mediação começa a penetrar nessa relação. 
"Não tem diferença emocionalmente [a relação mediada]. Pode ser que fisicamente tenha muita diferença. Emocionalmente não tem diferença. Pra mim o emocional vale muito mais do que o físico. Eu e minha mãe, por exemplo, a gente sempre se deu supermal, depois que a eu fiquei 'aborrecente', chata, a gente brigava todo dia. Todo dia era uma briga horrorosa. Ela mudou pro interior, e a gente se vê muito menos... A nossa relação melhorou mil vezes, porque ela me manda um SMS bonitinho, eu vou e entro no messenger, a gente se conversa pelo Skype, ela tem saudades de mim. Não sei, melhorou nossa relação." (Fabiana)

"Ah... na verdade não, né. Porque assim, né. A minha mãe e meu pai... O meu padrasto e a minha madrasta, ninguém usa Twitter ou Facebook. Outro dia eu ensinei minha mãe a usar o Facebook. Ela não tinha nem conta. Estavam convidando e ela queria entrar. Eu a coloquei dentro do Facebook e falei: 'usa assim, assim, assim...' $E$ ela tá curtindo, entendeu? Quer dizer, eu acho que, ao contrário, é, eles acabam entrando na rede porque a gente já tá lá. Mas, assim, a minha comunicação, por exemplo, com o meu pai melhorou muito por e-mail. A gente conversa muito por e-mail. Eu escrevo, ele escreve. Pê, pê... pá, pá... a gente conversa. Ele é duro de telefonar, ele nunca me telefona, mas ele me manda e-mail. Às vezes, ele manda 'sinais de fumaça' por e-mail. $E$ é bacana isso. $E$ a minha mãe também. E agora ela está aprendendo a usar o MSN. Ela já está começando a dar um 'avanção' de uso de tecnologia mesmo." (Diana)

"Com minha mãe... assim que a internet... ela também trabalha com computador acessível. Então a gente acaba conversando mais por email do que pessoalmente. Assim, 'filha faz isso pra mim'. Aí manda no e-mail e aí eu vou lá e faço. Então acho que até os pais precisam 
evoluir pra acompanhar o ritmo dos filhos. Pra isso também... porque aí acaba faltando comunicação mesmo." (Bia)

Esses relatos são extremamente interessantes e curiosamente se relacionam com os pais. Nas entrevistas, os pais e familiares eram relatados com especial atenção quando se mencionava o modo de se relacionar. Possivelmente, esse dado indica que os vínculos estabelecidos nas relações entre pais e filhos sejam de uma qualidade diferente, mais primitiva, profunda e direta, ainda que a mediação tome lugar das trocas imediatas.

\subsection{TICs, vínculos e políticas}

A temática dos vínculos nos relacionamentos mediados pelas TICs parece ficar ainda mais complexa tendo em vista a análise de seus possíveis desdobramentos políticos. Façamos aqui uma breve reflexão a respeito de um debate recorrente entre defensores e críticos das consequências das TICs.

Os críticos às TICs afirmam que a atual sociedade vive a crise da experiência como história, partindo do pressuposto de que as narrativas aprendidas, compartilhadas e vivenciadas no âmbito do comunitário são experienciadas pelo indivíduo integralmente nessas trocas intersubjetivas e integrais. A noção de pertencimento e de imbricação numa tessitura social permite identificações, projeções, introjeções que processem a constituição da 
identidade dentro de um contexto sociocultural, num determinado lugar e ao longo do tempo. A imagem de si mesmo é reconhecida nessa sociedade e é no convívio e nas trocas, constantemente legitimadas, um processo dialético no qual seu pertencimento ao grupo também pressupõe trocas intersubjetivas carregadas de conteúdos sensíveis. Essa coesão grupal estrutura e consolida a presença do indivíduo no mundo e este pode se colocar de modo seguro, pois está amparado por uma historicidade grupal, doadora de diversos sentidos e, sobretudo da sensação de confiança e de perenidade.

Para os críticos, as relações mediadas pelas TICs seriam incompatíveis com essas experiências que são obrigatoriamente imediatas, intersubjetivas, coletivas, presenciais e integrais. Se não se processam as experiências, a historiografia também não pode se constituir. Desse modo, o cenário da crise da experiência enquanto história - descrito por frankfurtianos, com destaque para Adorno e Marcuse - é povoado por indivíduos regredidos a um estado présimbólico com total hegemonia da técnica nesta sociedade administrada. O estado pré-simbólico, ousando uma leitura psicanalítica, é devido ao desamparo quanto às trocas com as instâncias doadoras de sentido, segundo Klein ${ }^{40}$ (1975), no primeiro momento o olhar da mãe que internaliza o objeto. O

\footnotetext{
${ }^{40}$ KLEIN, Melanie. O sentimento de solidão, nosso mundo adulto e outros ensaios. $2^{\text {a }}$ ed. Rio de Janeiro: Imago, 1975.
} 
processo que Winnicott (1988) delineia como desenvolvimento do sujeito da elevação do pré-simbólico ao simbólico envolve o criar por meio da destruição dos objetos fundando o princípio de realidade. Aqui a teoria crítica está profundamente harmonizada com a psicanálise.

A sociedade administrada não lida com a criação. A criação está no reduto daquilo que é próprio da subjetividade do homem e que atinge sua expressão máxima na arte. A lógica da sociedade administrada não é a criação, é a repetição ou, conforme Alain Touraine (1994), não se tem mais produção e sim reprodução. Tendo em vista que essa repetição está calcada em bases muito primitivas, o ser regredido observado pelos pensadores críticos às consequências da pós-modernidade é vítima de dupla violência. Antes de mais nada foi privado de se desenvolver adequadamente sendo incapaz de significar e de criticar adequadamente o panorama em que se insere, estando limitado a relações parciais com objetos igualmente parciais e fragmentados. A segunda violência está na restrição de toda sua experiência aos imperativos de suas pulsões. A teoria crítica alinhada com o materialismo histórico dialético, compreende que o desenvolvimento histórico do modelo econômico vigente origina, não somente, relações de produção capitalistas-mercantis, mas também produz relações sociais permeadas pela lógica do capital. Este ser desamparado descrito pelos críticos é o mesmo que com bestialidade consome a mercadoria falaciosamente dotada ou capaz de suprir o desejo que perpetua insatisfeito. Os 
atos de barbárie podem ser compreendidos dentro desse contexto de tamanha violência, desamparo e nonsense. Lasch (1999) descreve:

[...] é possível ver que o colapso da nossa vida comum empobreceu também a vida privada; libertou a imaginação dos constrangimentos externos, mas, ao mesmo tempo, a expôs mais diretamente à tirania das compulsões e ansiedades internas. A fantasia deixa de ser libertadora quando ela se solta dos controles impostos pela experiência prática do mundo. Em vez disso, ela dá lugar às alucinações; e o progresso do conhecimento científico que deveria desestimular a projeção de nossos anseios e receios interiores frente ao mundo que nos circunda, deixa intocadas essas alucinações. (Lasch, 1999)

Desde Delumeau (1989) a Bauman (2006), este é um cenário tão desestruturado e opressivo: o medo oprime a todos nós com consequências cada vez mais selvagens. É dentro de uma argumentação teórica que segue essa linha que os críticos às TICs rejeitam as relações mediadas.

A argumentação daqueles que se opõem à concepção de crise da experiência como história, os defensores das qualidades das relações mediadas pelas TICs afirmam que a historiografia, que é basicamente constituída por narrativas, calcadas na linguagem, não é afetada e se constitui por meios tecnológicos, pois a comunicação é efetiva e real. Muito embora a experiência 
humana integral não seja possível por conta de toda mediação técnica, as narrativas acontecem e potencializam as capacidades humanas. É possível por meio das muitas redes digitais acessar simultaneamente diversos canais e atingir um número sem precedente de pessoas com a possibilidade de interagir retroativamente e buscar tarefas em comum, interesses em comum ou simplesmente afinidades ou disposições de se estabelecer contato mediado para, quem sabe, se for do interesse de ambas as partes, realizar um encontro físico de trocas não mediadas.

Além das relações de foro íntimo mediadas pelas TICs, Egler (2007), num trabalho desbravador e inspirado pela metodologia de Bourdieu no tocante aos processos, desenvolvimentos e incorporação dos conhecimentos, historiografou suas pesquisas partindo da percepção da mudança nas relações espaçotemporais que presumidamente se sobrepunha à cidade industrial. No entanto, em suas pesquisas posteriores revelou ser uma tessitura mais intrincada na qual as redes digitais foram aumentando em complexidade e ramificações e englobando diversas esferas da vida social econômica e política.

A pesquisa proposta interroga sobre a ampliação do uso de Tecnologias de Informação e Comunicação (TICs) por atores públicos e privados. Para tanto, analisa como as políticas urbanas são definidas pela participação de novos atores que transforma a arquitetura das instituições e as possibilidades de interação social, sendo que a inovação dada pela cooperação, mobilização e ação 
coletiva suscitadas pelo uso dessas tecnologias redefine as relações entre estado e sociedade, quando substitui políticas urbanas tradicionais por outras formas mais interativas e mediadas por redes sociotécnicas. (Egler, 2007)

Outro arquiteto afeito ao estudo das TICs e seus efeitos na arquitetura e na vida das pessoas é Mitchell (2002), que afirma que desde os anos 1960, depois que Louis Khan incutiu na arquitetura a distinção funcional entre áreas úteis e de convívio humano e áreas satélites, de serviços para as áreas úteis, os tecnólogos tem copiado a lógica arquitetônica e sistêmica para as redes e viceversa.

As constatações de Egler (2007) são intimamente compatíveis com algumas das considerações deste trabalho a partir dos dados encontrados nas entrevistas. O que leva a crer que o resultado de ambas as pesquisas, colocados a prova, originam dados consistentes. A autora tem grande afinidade com o pensamento crítico de Hannah Arendt e Jürguen Habermas, teóricos de quem extrai interessante argumentação em torno da organização, volição e operatividade dos homens na sociedade, no processo de construção e ação coletiva realizado na esfera pública de modo autorregulado para explicar analogamente o funcionamento das redes sociotécnicas. Sua metodologia foi capaz de angariar dados valiosos não somente com relação ao modo de se pesquisar redes sociotécnicas e políticas públicas, mas também de 
compreender a dinâmica dos atores políticos em relação na arquitetura dessas organizações.

Pensar políticas públicas a partir de redes sociotécnicas é de vital importância, e este trabalho também tem o objetivo de investigar alguns aspectos desse tema tão novo para, possivelmente, auxiliar de alguma maneira o trabalho de se estruturar políticas públicas de articulação das redes.

Embora o desenvolvimento das tecnologias tenha diminuído os custos para a aquisição de um computador pessoal, e a infraestrutura das TICs no Brasil tenha aumentado e difundido o acesso à internet e o uso de celular, há um grande abismo entre as problemáticas discutidas aqui e a realidade da maioria dos brasileiros que não tem acesso e conhecimento para utilizar com autonomia as TICs. Essa consciência da desigualdade apareceu na coleta de dados de uma das entrevistadas, que é pesquisadora. Embora o relato seja extenso, é extremamente valioso e exemplar:

"A palestra que eu dei foi resultado de um Projeto [...] que eu tenho a coordenação nacional dele desde 2008... que eu coordeno este projeto. É um projeto na área da saúde, trabalho e cultura e é um projeto de inserção digital. Este projeto de inserção digital se utiliza... tem como dispositivo a cultura digital, uso de celulares, da máquina fotográfica, onde os trabalhadores utilizam isso para se autorrepresentar. E tem todo um processo de reflexão sobre esta autorrepresentação, de discussão, de elaboração, de entendimento disso. $E$ depois de condições de alternativas. $E$ depois de todo esse processo, então, existe a construção de redes sociais. Então nós temos hoje quase setecentos trabalhadores inseridos numa rede 
discutindo sua vida, seu trabalho, construindo alternativas e construindo redes de comunicação e discussão de cidadania.

"Este projeto surge como demanda dos trabalhadores. [...] que ocorreu em 2005. Uma das principais demandas dos trabalhadores era a visibilidade. Seja a visibilidade das condições de vida, seja a visibilidade das condições de trabalho. Mas eles queriam uma visibilidade não a partir do olhar do técnico, mas a partir do seu próprio olhar. Então, a visibilidade deste projeto está sendo construída a partir da autorrepresentação dos trabalhadores sobre sua vida, seu trabalho. Trabalhador é sujeito e objeto da sua própria construção desta visibilidade. [...] gente se utiliza da educação popular como principal referencial teórico do processo de formação. Então nós utilizamos a educação popular que tem um pressuposto fundamental para a construção do conhecimento de forma coletiva. $E$ esta construção do conhecimento se dá de forma coletiva e ao mesmo tempo se discute de uma forma mais crítica a realidade e se constrói alternativas a respeito. É todo um processo de formação que utiliza do pressuposto teórico da práxis. Ou seja, da ação, da reflexão e de uma nova ação. Este é o principal pressuposto teórico. Os trabalhadores, eles são capacitados para a utilização do vídeo, da máquina fotográfica, do celular (eles usam o celular) e depois desta utilização da inserção disso no site e no trabalho em rede. Então eles tem uma primeira formação que é essa. Mas a formação é continuada. De 15 em 15 dias eles se encontram com uma rede de apoio (com a rede), onde a universidade participa... mostram o que eles produziram. Colocam qual é o significado daquilo que eles produziram. E a partir do olhar da produção de um, se discute o todo. Porque, de um modo geral, a produção de um tem que ver com a produção de todos. E a partir deste trabalho, da produção de um, da história de vida de um se discute o todo... discuti as questões mais gerais. E depois deste trabalho que é feito de $15 \mathrm{em} 15$ dias tem toda a construção da rede social, onde também é o processo de 
formação, de troca, de discussão, de intercâmbio, de relações que se dão... Então nós temos um processo de formação contínua presencial e também na internet, virtual. (Ingrid)

José de Souza Martins, em seu livro Exclusão social e a nova desigualdade (1997), destaca que a exclusão não existe, o que existe é a contradição e as vítimas dos processos sociais, políticos e econômicos excludentes. Essas vítimas e suas reações de inconformismo não se dão fora dos sistemas econômicos e dos sistemas de poder, elas fazem parte deles ainda que os neguem. Em suas palavras: "As reações não ocorrem de fora pra dentro; elas ocorrem no interior da realidade problemática 'dentro' da realidade que produziu os problemas que as causam". Segundo o autor, a exclusão seria apenas um momento da percepção das diversas privações que vitimizam o outro. $\mathrm{O}$ atual modelo neoliberal brasileiro perfaz uma inclusão precária, instável e marginal se conformando como políticas de inclusão de pessoas nos mais baixos níveis da produção e circulação de bens e serviços, inserindo assim, utilitariamente na reprodução do capital, nas palavras de Bader Sawaia (2002) "inclusão social perversa". 


\section{Conclusões e indicações para um trabalho posterior}

A atualidade do tema e as diferentes análises possíveis dos fenômenos advindos das interações e dos vínculos mediados pelas TICs, nos convida a um olhar flexível e uma observação muito cuidadosa quanto ao modo que os processos relacionais se dão, da mesma maneira quais elementos subjazem aos processos e quais suas consequências visíveis e possíveis. Nas entrevistas, constatou-se que a pesada crítica negativa de autores da tradição sociológica não era totalmente válida, tendo em vista que os indivíduos têm encontrado por meio das TICs, diversas formas de se articular e provocar ações coletivas significativas no mundo, potencializando o sentido político de suas ações e possibilitando uma historiografia inscrita no real e articulada pelo digital.

Por outro lado, o cenário paradisíaco da comunhão das redes e comunidades, aldeias globais, como apregoa Lévy, está longe de se concretizar. Nesse sentido, muitas das constatações dos críticos às TICs se fazem válidas para o entendimento das relações e dos processos numa história que descreve, permitindo uma apreensão dos fatos, um posicionamento e uma ação frente aos modos insidiosos como as relações mercantis afetam profundamente os indivíduos e como a alienação impede uma compreensão e uma ação frente a essa realidade.

Os dados sugerem que os vínculos estabelecidos sem mediação são tratados de modo qualitativamente diferentes e não se alteram com a mediação. 
Inclusive os vínculos familiares - cujo convívio na intimidade exige tolerância quanto à subjetividade do outro e que traz alegrias, mas também frustrações foram relatados como beneficiados pelas relações mediadas. Acreditamos que, de certo modo, haja uma percepção difusa de como as TICs, intermediando os vínculos humanos, têm consequências e de que essa mediação afeta de alguma maneira as subjetividades. Tais efeitos e consequências passam incólumes pela crítica da maior parte dos usuários que, como apontado ao longo deste trabalho, possivelmente não tem instrumentos nem referenciais para pautar sua opinião. Não obstante, não tem tempo nem lugar definidos nos quais possam se basear, já que com o desamparo de seu sistema de significações comuns aos seus contemporâneos permanece alienado de si mesmo, dos outros e, sobretudo, de uma historiografia de onde poderia erigir algum tipo de comparação e previsão. Assim sendo, jamais chegando a se colocar criticamente frente ao rápido, imediato e incessante movimento dos meios digitais conduzidos pelos interesses de mercado focados no homem narcisista e desamparado dos dias de hoje.

De modo semelhante, o caráter difuso e abrangente e a rapidez com que as mudanças na internet se processam dificultam a sua análise pelos acadêmicos, que, também tomados pela lógica da produção nas instituições de ensino superior, acabam muitas vezes aumentando com pouca crítica, historiografia e validade o já volumoso e questionável conteúdo de informações da rede. 
As recentes revoluções do mundo árabe, potencializadas pelas redes na internet e as consequências econômicas imediatas no nosso mundo globalizado, o papel emancipador da arte como instrumento de transcendência por excelência, arte e tecnologia, a função do corpo como suporte primeiro e final da experiência, a mediação tecnológica nos vínculos entre crianças e adolescentes e políticas públicas de articulação das TICs, são alguns dos interessantes assuntos não pormenorizados neste trabalho, mas que despertam curiosidade.

De todos os autores aqui discutidos, Manuel Castels, em $A$ galáxia da internet, é o que mais se aproxima do nosso posicionamento quanto aos desdobramentos da relação do homem com as TICs. Para ele, este cenário ainda tem muitos desafios a serem superados e, na nossa opinião, somente um posicionamento de constante reflexão e questionamento será capaz de adentrar e doar sentidos para este complexo e fascinante panorama.

Este trabalho tem a intenção de reafirmar a propriedade do estudo dos vínculos e relações humanas para psicologia, bem como de buscar intersecções possíveis entre os diversos ramos da ciência, em especial, as ciências sociais e a filosofia, que nos auxiliam para compreender o complexo e difuso estado em que se encontra o homem na atualidade. A extensão do tema escapa aos limites deste trabalho e os questionamentos que ele suscita. Mais que as indagações que problematiza, servem de inspiração e um convite para desenvolvimentos dessa linha de pesquisa tão própria à psicologia social. 


\section{Bibliografia}

BAUDRILLARD, Jean. A sociedade de consumo. 1aㅡ ed. Lisboa: Edições 70, 1975.

. O sistema dos objetos. 1a ed. São Paulo: Perspectiva, 1973.

- Para uma crítica da economia política do signo. $1^{\underline{a}}$ ed. Lisboa:

Edições 70, 1995.

BAUMAN, Zygmunt. Amor líquido. 1a ed. Rio de Janeiro: Jorge Zahar, 2004.

. O mal-estar da pós-modernidade. $1^{\underline{a}}$ ed. Rio de Janeiro: Jorge Zahar, 1998.

. Medo líquido. $1^{\mathrm{a}}$ ed. Rio de Janeiro: Jorge Zahar: 2006.

BECKER, H. Métodos de pesquisa em Ciências Sociais. $4^{\underline{a}}$ ed. São Paulo: Hucitec, 1999.

BOGDAN, R. \& Biklen, S. Investigação qualitativa em educação. Portugal: Porto, 1994.

BOSI, E. O tempo vivo da memória. Ensaios de psicologia. São Paulo: Ateliê, 2003

BOURDIEU, P. (org.). A miséria do mundo. Petrópolis: Vozes, 1993.

. Contrafogos: táticas para enfrentar a invasão neoliberal. Tradução Lucy Magalhães. Rio de Janeiro: Jorge Zahar, 1998. 151 p.

CASTELLS, Manuel. A galáxia da internet: reflexões sobre a internet, os negócios e a sociedade. $1^{\underline{a}}$ ed. Rio de Janeiro: Jorge Zahar, 2003.

. "A sociedade em rede". Em $A$ era da informação: economia, sociedade e cultura. 4ª ed. São Paulo: Paz e Terra, 2000.

. "O poder da identidade". Em A era da informação: economia, sociedade e cultura. 4ª ed. São Paulo: Paz e Terra, 2000.

. "Fim de milênio". A era da informação: economia, sociedade e cultura. 4⿳亠丷a ed. São Paulo: Paz e Terra, 2000. 
CHAUÍ, Marilena. Simulacro e poder, uma análise da mídia. São Paulo, Fundação Perseu Abramo. 2006.

COSTA, Ana Cláudia A. IRC: uma nova alternativa para as relações entre as pessoas. 2001. Dissertação de mestrado. Departamento de Psicologia, Pontifícia Universidade Católica do Rio de Janeiro, Rio de Janeiro, 2001.

DENZIN, N. K. \& LINCOLN, Y.S. (orgs.). Handbook of qualitative research. $2^{2} \mathrm{ed}$. Thousand Oaks: Sage, 2000.

EGLER, Tâmara Tânia (org.). Ciberpólis: redes no governo da cidade. Rio de Janeiro: 7Letras, 2007.

GIDDENS, Anthony. As consequências da modernidade. 6aㅡ. ed. São Paulo: Editora Unesp, 1991.

GOFFMAN, Erving. A representação do eu na vida cotidiana. $2^{\mathrm{a}}$ ed. Petrópolis: Vozes, 1983.

GOMES, L. G. N. Implicações políticas das relações de amizade mediadas pela internet 2010. 264 p. Tese de doutorado. Instituto de Psicologia, Universidade de São Paulo, São Paulo, 2010.

HABERMAS, Jürgen. Der Philosophische Diskurs der Moderne. Frankfurt: Suhrkamp, 1985.

HOBSBAWM, Eric. Era dos extremos: o breve século XX, 1914-1991. 2ª ed. São Paulo: Companhia das Letras, 1996.

KLEIN, Melanie. O sentimento de solidão, nosso mundo adulto e outros ensaios. $2^{\mathrm{a}}$ ed. Rio de Janeiro: Imago, 1975.

LASCH, Christopher. O mínimo eu: sobrevivência psíquica em tempos difíceis. São Paulo: Brasiliense, 1999.

LÉVY, Pierre. A conexão planetária: o mercado, o ciberespaço, a consciência. São Paulo: Editora 34, 2001. . O que é o virtual? São Paulo: Editora 34, 1996. . Tecnologias da inteligência. São Paulo: Editora 34, 1998.

LIPOVETSKY, Gilles. A felicidade paradoxal: ensaio sobre a sociedade de hiperconsumo. 1ํㅡ. ed. São Paulo: Companhia das Letras, 2007. 
LYOTARD, Jean-François. Moralidades pós-modernas. $1^{\underline{a}}$ ed. Campinas: Papirus, 1996. . O pós-moderno. 3ㄹ ed. Rio de Janeiro: José Olympio, 1988.

MARCUSE, Herbert. Cultura y sociedad. 5a ed. Buenos Aires: SUR, 1970. Eros e civilização: uma interpretação filosófica do pensamento de Freud. 5 ${ }^{\mathrm{a}}$ ed. Rio de Janeiro: Jorge Zahar, 1972. Idéias sobre uma teoria crítica da sociedade. $1^{\text {a }}$ ed. Rio de Janeiro: Jorge Zahar, 1972.

MARTINS, José de Souza. Exclusão social e a nova desigualdade. São Paulo: Paulus, 1997

MARX, Karl. "O fetichismo da mercadoria e seu segredo". Em O Capital: crítica da economia política. 11 $11^{\underline{a}}$ ed. Livro 1. Vol. 1. São Paulo: Bertrand Brasil/Difel, 1987. p. 79-93.

MITCHELL, William J. E-topia: a vida urbana, mas não como a conhecemos. $1^{\text {a }}$ ed. São Paulo: Editora Senac São Paulo, 2002.

Nicolaci-da-Costa, Ana Maria. O cotidiano nos múltiplos espaços contemporâneos. Em Psic.: Teor. e Pesq. Vol. 21, no 3, Brasília: set.dez. de 2005.

PETERS, Michael. Pós-estruturalismo e filosofia da diferença: uma introdução. $1^{\text {a }}$ ed. Belo Horizonte: Autêntica, 2000.

PORTO, Sérgio D. (org.) Sexo, afeto e era tecnológica: um estudo de chats na internet. 1a ed. Brasília: Editora universidade de Brasília, 1999.

QUEIRÓZ, M. I. de P. O pesquisador, o problema da pesquisa, a escolha de técnicas: algumas reflexões. Em LANG, A. B. S. G. (org.). Reflexões sobre a pesquisa sociológica. São Paulo: Centro de Estudos Rurais e Urbanos, 1992. p. 13-29. (Coleção Textos. 2ª série, 3)

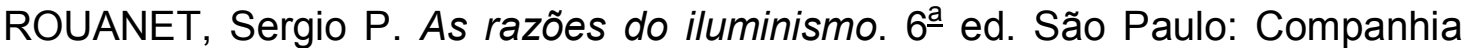
das Letras, 1999.

Mal-estar na Modernidade. $2^{\underline{a}}$ ed. São Paulo: Companhia das Letras, 2001. 
SAWAIA, Bader (org.). As artimanhas da exclusão. Petrópolis: Vozes, 2002.

SENNET, Richard. A corrosão do caráter: consequências pessoais do trabalho no novo capitalismo. 12 ${ }^{\mathrm{a}}$ ed. Rio de Janeiro: Record, 2007. . A cultura do novo capitalismo. 1ㄹ $\mathrm{ed}$. Rio de Janeiro: Record, 2006. . O declínio do homem público: as tiranias da intimidade. $2^{\underline{a}}$ ed. São Paulo: Companhia das Letras, 1989.

TOURAINE, Alain. Crítica da modernidade. 6a ed. Petrópolis: Vozes, 1999.

WOLTON, D. Internet, e depois? Uma teoria crítica das novas mídias. Tradução Isabel Crossetti. Porto Alegre: Sulina, 2003. 
ANEXOS 
ANEXO A - Roteiro de entrevista

Iniciais: Sexo: Idade:

Escolaridade: Profissão:

1. Quais tecnologias ou serviços você conhece e/ou utiliza pra se comunicar? Com que frequência?

2. Você conhece pessoalmente todos seus contatos das redes sociais, fóruns, blogs e comunicadores instantâneos?

3. Há alguma diferença entre aqueles que conhece pessoalmente e os "contatos virtuais"?

4. As pessoas com quem você se comunica são as mesmas com quem costuma se reunir?

5. A internet, o celular e as tecnologias da informação afetaram de alguma maneira sua relação profissional com as pessoas? E no âmbito pessoal? E no âmbito familiar?

6. O diálogo na internet, nos comunicadores instantâneos e nos SMS tem alguma diferença com relação ao diálogo presencial?

7. Na sua opinião quais são as principais vantagens e desvantagens das formas de comunicação mediadas pelos meios de comunicação digital? 


\section{ANEXO B - Termo de Consentimento Livre e Esclarecido}

Declaro para os devidos fins que concordo em participar da pesquisa intitulada: "Influências da comunicação digital nos vínculos humanos" e autorizo Vitor Muramatsu, mestrando do Instituto de Psicologia da USP, utilizar a minha entrevista, desde que meus dados sejam mantidos em sigilo. Sei que tenho o direito de recusar ou encerar a entrevista, como também vetar o uso de partes da entrevista concedida. O pesquisador explicou que esta pesquisa servirá para compreender quais implicações do crescente advento das tecnologias da informação e investigar as maneiras como se estabelecem as relações atualmente. Portanto, fui informado sobre os objetivos do trabalho de pesquisa. Sei que minha participação neste estudo é voluntária. Estou livre para recusar ou encerrar a entrevista de acordo com a minha disponibilidade. Aceito que as informações obtidas neste estudo sejam publicadas em revistas científicas e apresentadas em congressos, desde que nenhum participante ou instituição seja pessoalmente identificado.

São Paulo, de janeiro de 2011.

Vitor Muramatsu

Assinatura do Entrevistado
Assinatura do Pesquisador

Obs. Para esclarecimentos adicionais poderei entrar em contato com Vitor Muramatsu através do telefone (11) $9252-5162$ ou e-mail: vitor.muramatsu@usp.br ou ainda através do Comitê de Ética em Pesquisa com Seres Humanos do IPUSP: Av Prof. Mello Moraes, 1721, Bloco F, sala 22, Cidade Universitária - São Paulo, SP - fone: (11) 3097-0529. 


\section{ANEXO C - Entrevistas resumidas}

ALEX, 24, desenvolvedor.

V - Você tem familiaridade com as tecnologias da internet?

B - Sim, eu tenho bastante familiaridade com tecnologias digitais. A internet, ela por um lado, ela é só o fato dos computadores estarem conectados né. Mas por outro lado ela também é um mecanismo de organização social, sabe? É, posso dizer, é como o telefone né, o telefone na verdade é um bando de fio de cobre, mas o fenômeno do telefone em si é a possibilidade de eu ligar pra alguém e dizer: 'olha 5 horas da tarde em tal lugar'. Então no sentido, as tecnologias que nós trabalhamos são tecnologias estritamente digitais que não dependem necessariamente da internet, mas a articulação do trabalho a possibilidade de a gente contribuir com o registro de nossas experiências na procura de como tratar estas informações, e o fato de a gente poder registrar isso na forma de algoritmos, de a gente poder contribuir isso pro outro trabalhar à distância, trabalhar em situações que normalmente requereriam algum mecanismo de comunicação mais imediato. $E$ a internet acaba cabendo bem aí, no meio, faz com que a gente tenha um desempenho muito bom. Então eu diria assim, no sentido de tecnologias, nós temos bastante, nós aliás que trabalhamos com transparência e software livre, temos um certo domínio da tecnologias digitais, mas mais que tudo né, temos um legado ou uma experiência de comunidade que se construiu em cima da internet.

\section{$V$ - Com que frequência você utiliza a internet?}

B - Diariamente durante bons períodos do meu dia, considerar que eu trabalho aproximadamente 8 horas por dia e que a maior parte do meu trabalho se dá produzindo pra internet ou produzindo a partir da internet, então um terço do meu dia, pelo menos, eu estou conectado.

$\mathrm{V}-\mathrm{E}$ depois que você para de trabalhar, você continua na internet?

B - É comum eu guardar leituras pra fazer depois do meu horário de trabalho. 0 uso de email e mensageiros instantâneos é assim, recorrente, é um mecanismo primário pelo qual eu consigo me comunicar com meus pais, que moram em outra cidade, com a minha esposa, quando eu não estou no mesmo lugar que ela, com meus amigos, quando nós temos que combinar alguma coisa pra sair e tal. É porque, principalmente por ser um meio muito mais barato do que o telefone ou o telefone celular. Então, embora ele não seja tão imediato que eu posso te mandar uma mensagem pra você estar ouvindo como é no telefone, ele com certeza é muito mais barato e por conta disso mesmo possibilita que eu faça mais interações durante o dia e tente um pouco mais de insistência organizar alguma coisa tipo, sair no fim de semana ou algo assim.

V - As pessoas com quem você fala na internet são as mesmas pessoas que você encontra? 
B - Essencialmente a maior parte das pessoas com quem eu interajo diretamente na internet ou são pessoas que fazem parte do meu cotidiano no meatspace ${ }^{41}$, no espaço de carne mesmo, ou são pessoas que eu compartilho experiências através do algoritmo mesmo. Então são pessoas com quem eu compartilho experiências através de códigos escritos ou mesmo de textos escritos, tentando tratar de temas diversos numa cultura de compartilhamento que acaba aproximando muito as pessoas. Então, ao mesmo tempo que eu mantenho durante o dia muita comunicação com pessoas com quem eu tô sempre em contato - minha mãe, minha esposa, meus amigos de faculdade -, eu tenho contato frequente com pessoas que colaboram comigo em desenvolver coisas novas ou em resolver problemas de experiências que nós já tivemos juntos antes, mas todos mediados pela internet.

$V$ - Você acha que tem alguma diferença entre essas amizades das pessoas que você conhece e das pessoas que você não conhece?

B - Bem é... As pessoas que a gente conhece pessoalmente elas têm laços que são tratados imediatamente. Então, por exemplo, uma mania da pessoa, algum traço da pessoa que seja incômodo ou o contrário, alguma coisa que seja muito atraente tem um impacto imediato muito grande, enquanto pela internet eu posso estar conversando com um cachorro verde do espaço que essencialmente o que interessa é aquela interação mais do que a pessoa em si. Então, por exemplo, se eu tenho uma briga com um parente ou com um amigo próximo, eu vou ficar magoado naquela interação, estamos brigando, mas não deixa de ser um amigo, não deixa de ser meu parente. A gente vai tendo esta interação. Pela internet é a interação que está em primeiro lugar. Então se eu estou tratando com uma pessoa que não está disposta a colaborar com alguma coisa, eu não tenho motivo pra continuar a interação justamente porque eu tenho um volume muito grande de outras pessoas com quem eu posso ter essa mesma interação, dentro daquele mesmo escopo. Se eu estava procurando alguém que me ajudasse a desenvolver tal coisa, e esse alguém que eu encontrei foi, teve, uma experiência ruim... ou nós, não consegui colaborar com ele e tal, pula pro próximo, sabe? Inclusive não tem é... mágoas. Entendeu? Tipo, 'ah, tentou, não deu, bola pra frente', sabe? Tem pessoas e pessoas , formas e formas de trabalhar ou de colaborar que não dependem exatamente de duas pessoas pras mesmas coisas juntos.

$\mathrm{V}$ - Bom, eu acho que as redes sociais na internet ou todas as redes de compartilhamento e outras coisas mais que a gente tem agora, elas ajudaram a unir algumas pessoas e algumas ideias. Você consegue ver alguma diferença dos grupos que a gente tem digitalmente dos grupos que a gente tem na vida real ou como a gente tinha antigamente?

B - Essencialmente por baixo, a essência é a mesma, então nós temos o mesmo fenômeno, que são pessoas que precisam se organizar para algum fim determinado e vão procurar os meios mais interessantes pra isso. Internet, no começo foi o telefone e assim teria sido a carta ou as assembleias, mas uma das possibilidades que a internet dá, na verdade que os meios digitais dão, é primeiro você ter a liberdade em relação ao espaço e ao tempo, porque você continua uma discussão mesmo que não estejam todos presentes

${ }^{41}$ Terminologia oriunda da literatura cyberpunk significando a vida de carne e osso em oposição à vida no espaço virtual (cyberspace). Termo utilizado entre internautas para designar atividades da vida real ("RL" real life), afastada do teclado do computador ("AFK":away from keyboard). 
ao mesmo tempo, cria uma discussão mesmo que estejam todos distantes. Então a esfera da discussão, ela se liberta destas limitações da presencialidade ao mesmo tempo que você tem uma relação de intimidade muito menor. Então por mais que você se esforce em divulgar, sabe, fotos do seu filho do seu dia dia, a música que você gosta, mas com esta troca de intimidade, a intimidade imediata né, que é a que acontece entre os indivíduos, ela não tem o mesmo espaço pra acontecer à distância em tempos diferentes. Então os laços são diferentes, os interesses, eu acho, que são os mesmos; eles sobrevivem às condições midiáticas. Se trocasse de mídia, de internet, por alguma outra mídia diferente, os interesses continuariam lá presentes se organizando da melhor maneira que eles pudessem se organizar, mas, na sua pergunta também a respeito do... eu me perdi agora.

V - Você teve alguma experiência semelhante de achar que conhecia alguém pela internet e quando conheceu era bem diferente? Ou o contrário.

B - Teve. Em diversas ocasiões eu encontrei pessoalmente pessoas que eu conhecia pela internet, eu me surpreendi, às vezes por ter uma expectativa diferente, sua expectativa, sei lá, era mais descolada. Ela era superquieta ou o contrário, mas em geral é muito uma surpresa de você não conseguir perceber tão claramente a personalidade da pessoa na internet, e aí quando você encontra a pessoa a personalidade dela tá ali né. Não está escondida atrás de um computador. Então na maioria das vezes é surpreendente, mas não por frustrar uma expectativa, ou por contrariar uma expectativa, mas por não haver expectativa, por não saber como não saber o que esperar de uma pessoa que você só conhece de algumas interações. Daí de repente você vai ter um contato mais direto.

$V$ - Essa interação via internet, ela parece na sua fala ser diferente qualitativamente das trocas reais do contato tête a tête. Que diferenças são essas?

B - Então, eu considero todas as trocas reais. Efetivamente eu tô fazendo uma troca, eu tô compartilhando alguma coisa dizendo 'olha aconteceu isso comigo ontem. Eu tava lá.' 'Olha comigo também.' E a gente lida e tal. É uma coisa real, mas a mediação tem uma coisa entre a gente. Talvez seja meio clichê o termo, mas tem uma coisa entre a gente que cria a comunicação, então por mais que eu tenha uma habilidade literária em expressar, sei lá, coisa e tal um choro ou uma reclamação chega na outra pessoa na forma de palavra dura no computador. Ela não tem a mesma característica imediata para ver a pessoa na sua frente, a comunicação... ela se dá essencialmente de forma verbal. Você tem webcam e tal que facilita mas não é, não é o recorrente. Não falo o tempo inteiro no skype com as pessoas, e eu diria inclusive que não é interessante. Você não tem uma procura estar no skype com todo mundo que você conhece na internet porque é um esforço de atenção, você tá no MSN, tem trocentas janelas abertas. Você, na sua vida, de vez em quando você olha o que o cara escreveu e responde. No skype você tem que dar uma atenção um pouco mais direta e é pra alguém com quem você não tem uma experiência prévia. Você não tem uma intimidade, então não é, sabe, efetivamente pra eu realizar esta troca, não é o ideal, não se procura o skype, não se procura a webcam pra trocas entre estranhos, ou pelo menos eu não procuro. Exceto quando se trata de um passatempo especificamente constituído disto... ah vou ficar no chatroulette conversando com pessoas esquisitas. Mas a própria relação é meio irônica, meio de brincadeira, não tem um, "vou fazer um amigo" no chatroulette. É tipo... vou ver que coisa vou achar no chatroulette, uma exploração de surpresa, de certa maneira até trata o outro como sei lá uma caixinha de surpresa, ah a pessoa, mas apareceu sei lá um freak. Sabe, apareceu um espetáculo pra eu assistir alguma coisa diferente com quem eu vou interagir mas com quem eu não vou criar laços. Se fosse pra criar laços a própria constituição da interação seria diferente. 
V - Por exemplo, o que impede que a internet ou os comunicadores instantâneos sejam tão eficazes quanto o contato real?

B - A mediação é a barreira. Você ter um objeto que está entre as pessoas, essencialmente você está lidando com uma outra pessoa através de sinais, de códigos diversos, de... tipo então você não está lidando diretamente com a pessoa.

$V$ - Legal. Acho que na nossa conversa você trouxe várias coisas interessantes: bons usos da internet, das redes para, por exemplo, a libertação através de software livre, mas você também trouxe que algumas interações são bloqueadas pela própria limitação do instrumento. Qual sua opinião final a respeito do uso da internet? Você acha que é uma coisa legal ou não é muito legal? Qual seria sua sugestão a respeito do uso da internet, cuidados ou qualquer coisa assim?

B - É, tem uma lenda né das pessoas que se perdem né na interação artificial ou na interação mediada, e não voltam a ter interação com outras pessoas. Eu, não que eu evitei o fenômeno, não conheço pessoas que fazem isso, mas eu não enxergo isso como uma possibilidade. A internet é como o telefone, ela funciona pra eu poder ligar pra outra pessoa e me encontrar com a pessoa, e ao mesmo tempo ela funciona pra que eu conheça esta pessoa e tenha mais interesse em encontrar com essa pessoa. As limitações que a gente vê, na verdade elas se dão porque são coisas distintas. Eu não vejo como um obstáculo, um problema a ser superado, o fato da internet ser mediada ou seja ela ter esta distância entre este espaço pra poder... Pelo contrário, eu acredito que se não fosse este assim não teria este volume de interações. Se eu tivesse que ficar presente e estar imediato em todas as interações que eu tenho que fazer durante meu dia, é, eu não conseguiria fazer tantas coisas. Teria que controlar em um nível muito menor. Então eu não vejo um problema, eu vejo duas coisas diferentes. Com pessoas com quem eu já tenho uma relação imediata, uma relação sem mediação, eu quero preservar, o uso da internet serve apenas pra articular os momentos em que eu posso fazer isso. Tipo: eu não estou conversando com minha namorada pela internet porque eu namoro ela pela internet, tô conversando com ela pela internet porque é o meio que eu tenho de organizar quando que a gente vai se encontrar ou onde ou, em que circunstâncias... é uma maneira de preparar a imediação. Já com outras pessoas é... eu espero manter uma relação mediada até que me desperte o interesse de ir além disso. Se não houver o despertar de interesse pelas circunstâncias que é impossível uma afinidade nascer, então eu não vejo problema. Eu acho natural, natural no sentido amplo de natural, da nossa natureza passar pela imediação eu acho confortável, espontâneo, interessante, que evita o espaço que a gente fazia estas interações mais mediadas mais distantes e pelo espaço, inclusive o tempo do seu dia pra dizer uma coisa imediata. Então pra você não ficar em contato direto o tempo todo. São dois fenômenos separados. Nenhum deles deve se transformar pra compensar o outro. Pelo contrário, são dois fenômenos que inclusive, como eu falei, têm uma retroalimentação, contato com o resto do mundo me fazem querer conhecer mais pessoas mais diretamente porque justamente me apresentam uma pessoa com quem eu só posso interagir durante um bom tempo pela internet, mas não vejo como limitado vejo como condições diferentes ambas são muito interessantes.

Bia, 21, estudante.

$\mathrm{V}-\mathrm{E}$ você tem Twitter? 
A - Tenho Twitter. É uma rede assim bem interessante de usar né, porque ao mesmo tempo que você tá conectado com meio mundo, você não tem ninguém. Então fica aquele dilema né, proporcional, seria né ao mesmo tempo que você tá com todo mundo, conversando com o mundo inteiro - gente da Espanha de Portugal - você tá em casa, sem contato nenhum, com até família, com seus familiares, seu irmão... você acaba esquecendo um pouco o que você tem dentro de casa e querendo conhecer o mundo, conhecer o mundo entre aspas, porque você fala sozinho literalmente falando. E aí é muito interessante, eu particularmente gosto, eu uso. Assim dá pra expor minhas ideias, trocar ideia com todo mundo e passar o tempo, né?

$\mathrm{V}$ - O que você acha que acontece pra ter esta disparidade entre comportamento on-line e o comportamento na vida real?

A - Não, eu acho que tem muita diferença. Assim, porque não tá no olho-olho assim. Então acho que no computador você pode esconder muita coisa, até expressão, reação coisas que eu acho essenciais. E falam bem mais do que palavras expressão corporal, falam bem mais do que palavras. Então no computador fica escondido, e aí a pessoa fica meio que um robozinho simpático né, e pessoalmente a pessoa fica mais vulnerável né, fica qualquer coisa pode distrair é... dar entender alguma coisa sem falar um piu. E aí por isso que tem entra esta diferença por causa disso.

V - Você conseguiria citar rapidamente, ou o que vem a sua cabeça das vantagens e desvantagens da internet das tecnologias digitais.

A - A vantagem é que você pode conversar com um parente seu que tá no Japão sem sair da sua cadeira né. $O$ que eu acho que é essencial é fazer compra também; você não precisa pegar fila e nada. E a desvantagem é que você deixa de curtir o que tem dentro de casa assim, que você tem você pode estar com sua família, pode fazer uma coisa mais natural, cuidar do seu cachorro, sair pra andar e... então coisas simples que a gente acaba deixando né, deixando de lado por causa da internet.

\section{V - Você costuma ficar mais tempo on-line do que você deveria ou gostaria?}

A - Sim, quando eu falo "a gente" eu me incluo. Eu sou viciada. Sou daquelas que se eu for pro sítio que não tem internet eu fico angustiada assim. Não porque eu preciso, assim... é por uma forma de passar o tempo. Também eu acho que é essencial você ter conhecimento, ter alguma coisa pra fazer, sempre interagir, trocar informação. Eu acho que se você tem conhecimento e não pode conversar, não pode trocar, acho que conhecimento é em vão. Então as redes sociais de internet estão aí pra isso, né, pra trocar conhecimento, pra saber da vida do outro, tanto pra fofocar, pra falar bem, pra apoiar, até pra motivar. E eu consigo... eu não consigo sair da internet... assim eu posso, sei lá, andar, mas eu prefiro ficar na frente do computador. É melhor é mais confortável e é isso né."

$\mathrm{V}$ - O seu uso da internet das tecnologias digitais afetou de alguma maneira seu tempo de convívio ou a qualidade do seu convívio com sua família?

A - Com certeza minha família, com minha mãe... assim que a internet... ela também trabalha com computador acessível. Então a gente acaba conversando mais por e-mail do que pessoalmente. Assim, 'filha faz isso pra mim'. Aí manda no e-mail e aí eu vou lá e faço. Então acho que até os pais precisam evoluir pra acompanhar o ritmo dos filhos. Pra isso também... porque aí acaba faltando comunicação mesmo. 
A - Por e-mail, converso! Eu falo sobre namoro, falo sobre faculdade. Assim ela tá trabalhando muito por este fato, ela chega cansada e acaba não conversando comigo. E no trabalho ela tem essa possibilidade de estar conversando um pouco. Então é até melhor pra nós duas, porque eu não paro em casa porque eu trabalho e estudo né. Então é melhor pra nós duas.

V - Então você tá me dizendo que as tecnologias, elas ajudaram você a se aproximar ou conversar mais tempo com sua mãe... É isso?

A - É, no... na relação pessoal eu/minha mãe ajudou bastante pelo fato de tempo. Poupar tempo. Mas a gente sempre faz uns programas especiais no fim de semana, quando a gente tem tempo de conversar, sentar pra assistir TV. E ajudou bastante.

A - Então é na internet. Acho que é uma coisa mais, é assim não é aquela coisa quente de carinho, sabe? De é alguma coisa mais de conversar pra saber do outro assim, alguma coisa mais assim equilibrada, mais não tão pessoal. E quando eu converso com o pessoal em casa, que tem almoço sempre, é uma coisa: 'vem pra cá', 'vou te abraçar', 'vou te pegar'. É uma coisa assim mais humano, assim mais quente.

Carlos, 30, jornalista.

$V$ - E... uma coisa que a gente tem visto é que a tecnologia da internet e a velocidade com que comunicação é oferecida, ela tem potencializado alguns tipos de serviços que são congregadores de pessoas, como por exemplo, as redes sociais, os comunicadores instantâneos, os voips, e o próprio Twitter, que tá tão na moda. Mas o que você acha dessa comunicação? Você acha que ela vai estabelecendo efetivamente mais contanto entre as pessoas ou ela está estabelecendo mais comunicação?

D - Olha, você tocou agora num assunto muito, talvez delicado. Porque não adianta nada você (meu ponto de vista é assim...)... não adianta nada você ter.... vamos falar do Twitter... mil seguidores, mil pessoas interessadas em saber o que você faz, se você não conversa com essas pessoas. Porque aí fica uma coisa que era pra ser de mão dupla, fica mão única. Então você não tem o feedback, de repente, de alguém querendo saber é... o exemplo que citei... "Que carro que eu devo comprar? Tô na dúvida galera. Quero um Fiat ou quero um Chevrolet?" E ninguém responder. Pôxa, mas você tem mil seguidores. Porque essas pessoas.... Peraí, a grosso modo você está sozinho, você não está falando com ninguém. Você está falando com a parede, né. Então, o Twitter, as redes sociais muitas vezes podem, digamos, iludir e dizer que quanto mais melhor. Olha eu tenho 500 mil seguidores! Tá, desses 500 mil seguidores com quantos você fala? Com quantos ativamente você tem contato? Às vezes, a pessoa que tem 50 conversa com todo mundo, já teve oportunidade de conhecer todo mundo pessoalmente e continua estabelecendo contato com essas 50. Então, às vezes.... é o lance da quantidade e qualidade. Às vezes a quantidade não quer dizer nada. Hoje, por exemplo, no meu exemplo, no meu Twitter, (não vou saber quantos...) [no profissional] tem 950 pessoas. Se você entrar no Twitter, por exemplo, duma (que eu também trabalhei, vamos colocar aqui) vamos entrar no Twitter da Metropolitana, aqui em São Paulo, que é uma Rádio consolidada, com grande audiência, vem crescendo... a Metropolitana tem 63.854 seguidores. Eu questiono, eu jogo a pergunta: com quantas pessoas dessas $63 \mathrm{mil}$ e tanto eles ativamente falam? "Ah, mas não dá pra falar com todo mundo!".... Não, peraí. Não dá pra falar com todo mundo, mas você não precisa falar personalizadamente com todo mundo. Mas pra um nicho você pode, de repente tratar, de repente desses 63 mil seguidores, vamos supor, $10 \mathrm{mil}$ são por 
falta de um determinado programa, que gostam de determinada programação da rádio que compõe o todo. Às vezes um tweet bem feito você consegue falar com esses 10 mil numa tacada só. E aí, é claro, um ou outro desses $10 \mathrm{mil}$, talvez não seriam todos que respondessem. eE a partir daí você começa a criar os filtros. Este ouvinte, ele participa mais, este aqui falou uma vez, não veio buscar o prêmio, não falou nada com nada. Tá seguindo mas é a mesma coisa também como se não tivesse. Então quantidade não é qualidade. A [minha rádio] procura atender todos os nossos... por enquanto né... porque também a gente tem que ser realista, que 1.000 seguidores já começa, chegando já a quase 1.000 seguidores, você já começa a ter um pouco de... de... pedir mais tempo de dedicação somente a isso... é... começa a ficar um pouco complicado. Mas a gente, às vezes, por exemplo, aqui na Campus... depois que a gente veio pra cá, até hoje, a gente, aproximadamente, $\mathbf{3 0}$, quase $\mathbf{4 0}$ novos seguidores nós conseguimos. Todo final de dia ou todo início de manhã a gente procura mandar um "Seja Bem-vindo" aos novos seguidores. "Sejam bem-vindos os novos follows da [rádio] Brasil. Ouçam aí a programação. Peçam suas músicas. Sintam-se a vontade." Então, já falei com esta parcela. Eu vou começa a ter o filtro aí. O MSN, por exemplo, é a mesma coisa. Quando alguém adiciona... como no MSN é mais bate-papo, a gente costuma perguntar: "Oi, tudo bem?", "Tudo", "Qual o seu nome?", "Vitor", "Oi, Vitor, da onde você tecla e como descobriu a gente?", "Ah... eu teclo aqui de São Gonçalo, Rio de Janeiro", "A legal, como você descobriu a gente?", "Ah, no Google.", "Ah. Legal. Quer pedir uma música... quer..." A partir daí a gente começa a fazer o papel de companheiro, né... da companhia.

$V$ - Nesse sentido, tem alguma diferença entre seus amigos que você fez na vida real, digamos assim, e os que você conheceu pela internet?

D - Não. Não. O que muda aí, eu acho, é simplesmente o meio por onde se chega à coisa. Se você cresce numa rua, tem amigos desde a infância, tudo bem, são seus amigos. De repente, você conhece uma pessoa na internet e, em quatro meses, essa pessoa é tão amiga sua quanto alguém de infância. 'Ah, mas a internet é perigosa, a gente tem que ficar esperto, né.' Na vida real também é assim. Então, às vezes, eu acho que cai por terra aquele lance das pessoas falarem que 'Ah, você arrumou uma namorada, uma esposa na internet'. É possível, é possível. É, mas na internet você não sabe se essa pessoa é gente boa. Se você for sair para uma balada, for pra uma festa, enfim se alguém te apresentar um amigo, alguém apresentar: 'Olha, essa aqui é minha amiga e tá querendo te conhecer." Dependente... essa amiga não é a pessoa que você estava imaginando. Então, eu acho que só muda o meio aí. Ou via internet ou pessoalmente. Via internet talvez seja mais rápido, você chega em lugares onde você não chegaria... Você pode conhecer pessoas de outros estados, outras cidades, países. Pessoalmente, bom, beleza, quero conhecer alguém de Salvador. Então você vai pegar um avião, vai pra Salvador e dá uma volta por lá. É um pouquinho mais complicado. Aqui, nesta conversa, eu posso conhecer alguém, enquanto estou falando com você, no MSN, que esteja em qualquer canto do mundo. Então, acho que só muda isso.

Diana, 45, web designer.

\section{V - Então a ideia do "[nome suprimido]Camp" é o encontro e não a discussão, é isto?}

L - É o encontro e a discussão. Na verdade a gente forma uma rede de mulheres que estão na internet, usam a internet. No começo eram "blogueiras", né... porque é o que eu faço, era onde eu tava, e aí a gente abriu mesmo. A menina...a pessoa só tem o Twitter... a mulher só tem o Twitter entra no grupo entendeu. As vezes não tem nem nada. Ela vai aprender a usa Twitter, Facebook, blog, Wiki, tralalá, no grupo, entendeu. 
V - Qual a periodicidade dos encontros?

L - A gente faz 4 por ano... 3 regionais.... Normalmente são de 3 em 3 meses, né. Então é: março, junho, setembro é o nacional, e no fim do ano tem o último, quando a gente encerra $o$ ano.

V - Pelo que eu tô percebendo, você tá dizendo que o formato de vocês é de fato diferente comparado, por exemplo, ao Facebook ou ao Twitter?

$\mathrm{L}$ - Na verdade, na comunidade de blog, a gente tem esta tradição de se encontrar. Isto é uma tradição blogueira, tá, os blogueiros se encontram. A gente marca no Twitter, a gente usa as ferramentas de rede pra produzir encontros presenciais. Isto é uma coisa que blogueiro sempre fez desde que entrei, assim no ambiente "Globosfera" brasileiro. Eu sempre vi isto acontecendo... e lá fora também é assim. Blogueiros marcam encontro, encontram, trocam, um conhece o outro, Ah! um escreve no blog do outro, entendeu. Então, o blogueiro tem esta coisa gregária, mas presencial, mais perto, né. É uma coisa que a gente faz mesmo.

V - Que outros ambientes ou esferas da internet você vê o oposto, a tecnologia, de uma maneira menos gregária, por exemplo?

L - Acho que no Brasil, a tecnologia não desagrega. Por uma questão cultural... é uma sensação que eu tenho. Porque as pessoas no Brasil usam muito a tecnologia pra fica juntas, pra criar grupo, pra conversar, pra discutir, pra encontrar solução, pra trollar, enfim, pro bem e pro mal né sempre. Mas, eu acho que o brasileiro não tem essa coisa de trapaça, de trair, a não ser que o nego tenha uma neurose, uma psicose intrínseca, aí isso é dele, né, não é uma questão de rede. É a questão do ser humano que esta atrás da rede [ela quis dizer, por trás da rede]. Por que assim, eu tenho um caso na minha família, um irmão que tem um problema psicótico qualquer, que eu não sei dizer qual é exatamente, precisaria ligar pro psiquiatra dele [rindo] ... mas o cara é louco... em linguagem popular, ele é louco. Ele não usa a internet pra se comunicar. Ele usa a internet pra se isolar. E eu vejo que é isso...quem já tem a patologia vira patológico na rede também. $O$ que se faz na rede depende da pessoa que está na rede. Eu acho que acredito nisso piamente.

V - Então, na sua opinião, a tecnologia só vem a potencializar os encontros humanos?

$\mathrm{L}$ - Se os humanos quiserem se encontrar. Quer dizer, potencializar o desejo do humano, né. Eu diria, né, eu acho mais preciso. Porque se o ser humano que usar a tecnologia quer encontrar ele vai encontrar, se ele quer esconder, ele vai esconder.

V - Só para na hora de dormir?

L - Só para na hora de dormir. Porque é assim... O Twitter está no computador, no Smartphone, ele tá Galaxy Tab... Então assim, eu tô no Twitter o tempo todo, né. Às vezes eu tô lendo... eu uso muito o tablet pra ler né... Às vezes eu estou lendo no tablet e aparece lá o "fiu" do Twitter, porque o meu aplicativo de lá faz "fiu", e eu: "oba, o que está rolando?", que alguém me mandou alguma coisa, porque ele só "pia" quando alguém me "pita" né... Então eu sei que alguém está falando de mim. Mas é... eu adoro, porque é o jeito de eu falar com meus amigos, conversar, entendeu? Eu sei das coisas que estão rolando. 
$V$ - Certo, mas o Twitter não substitui em nenhuma medida seu relacionamento com essas pessoas né?

L - Nunca! Muito pelo contrário. Acessar o Twitter dá saudades das pessoas. Assim, dá vontade de ir ver. Então assim, a minha amiga de Montevidéu, o meu amigo de Florianópolis, a minha amiga de Brasília, o meu amigo que está no Rio agora... Eu pelo menos fico com mais vontade de ver as pessoas.

V - Algumas pessoas dizem que a questão da ênfase é muito difícil de ser passada através dos meios digitais. Como é que fica isso na comunicação com seus pais, por exemplo?

L - Ênfase no meio digital não existe. Não existe. Isto é fato. E tem que tomar muito cuidado com o "como", "o que" se fala no digital por conta disso. Agora, com os meus pais não tem esse problema, porque são textos muito pessoais. Então, não se desentendem, não se desentendem.

V - Quais as que vocês acham que são as tendências do desenvolvimento das redes sociais, dos comunicadores instantâneos, dessas redes de comunicação?

L - Olha, o que eu tenho visto é assim cada vez a integração maior. Uso o "login" do Twitter ou do Facebook pra "logar" em várias coisas. O meu quora que agora é a última moda né, já tá todo mundo grudando e seguindo...e se conectando e ah! me apaga, sua apague, lá, lá, lá ..e tá todo mundo grudando e assim, eu não sei pra onde vai, não dá pra saber... é muito "rizomático". Então, você fala assim: ah! vai pra lá. Mas vai pra lá, vai pra cá... vai pra lá, vai pra cá...lá, lá. Não sei pra onde cresce. Porque é um rizoma, né.

V - Você acha que as pessoas estão se encontrando mais, são mais felizes com essas facilidades da era digital?

L - Felicidade é uma palavra enganadora né. Muito enganadora. Eu não gosto dessa palavra assim.. Eu tenho o maior medo de "felicidade". Eu acho que a gente pode se satisfazer ou não com alguma coisa, né. Eu não acredito em felicidade, ponto. Felicidade é uma coisa que a propaganda tenta empurrar pra gente pra vender alguma coisa. Não existe felicidade, pra mim. Existe a satisfação... fazer o trabalho bem feito, entregar o que você prometeu, existem outras coisas em termos de "NIRVANA", vamos dizer assim [rindo de leve]. Mas...ah...e também não é um conceito de felicidade o "nirvana", né. É.., tem essa coisa, né... Eu sempre estudei muito Filosofia e tal. Então assim, não vem falar pra mim: "ah! felicidade, ..." Felicidade não existe, tá. Eu não me engano. A felicidade não existe. A felicidade é fundada, é uma coisa que... é muito volátil, né. Não existe. Então, acho que é assim... não depende do meio, não depende o que você usa, as pessoas cada vez mais vão ter que usar internet e vão cair na rede. Isso é quase inescapável, entendeu. Se elas vão usar o Twitter ou não, se elas vão usar o Facebook ou não, se elas vão usar Orkut ou não é uma questão de escolha. $O$ que pra mim, como profissional e como pessoa, é importante, é dizer: "saiba fazer sua escolha". É ajudar as pessoas a escolher bem dentro da rede, sabe Vitor... É uma coisa assim, acho que a função da gente que é mais nerd, mais crítico, sabe do que está falando é exatamente educar quem está chegando e não entende possa entrar na rede de uma forma bacana pra ele e não pra mim.

V - Explique o termo "faz parte da natureza", já que não nascemos dentro de um computador? 
L - Computador faz parte da natureza porque a gente criou o computador e criou o bicho no mundo né. Quando eu falo da natureza, não só falando da natureza no sentido natural, mas tô falando de um ecossistema. Porque a gente vive num ecossistema complexo, de vida e modo de vida, enfim em que o computador está inserido. Então o computador faz parte do sistema, do modo de vida. Por isso que eu falo parte da natureza. A rede social é parte da natureza. Da gente... humana.

Ernesto, 25, administrador.

\section{V - Como é sua relação com as redes sociais? É bem frequente?}

M - Não consigo ficar um dia sem entrar no Twitter. 0 blog atualizo diariamente de 2 a 3 vezes. O Facebook estou começando a mexer agora, não é muito a minha praia. O Orkut já "larguei de mão". Mas sem as redes sociais dificilmente me comunicarei com o tanto de pessoas que eu me comunico, ou não atingiria o número de pessoas que eu gostaria de conversar ou passar uma ideia.

$\mathrm{V}$ - De que maneira você consegue identificar a maneira que você comunica com as pessoas? Antigamente, antes da fama, você tinha um acesso mais restrito as pessoas, um grupo menor no MSN, como que é hoje com o Twitter?

M - O Twitter hoje tem 170 mil seguidores, entre blogs é o segundo Twitter maior entre blogueiros, só perde para o [concorrente]. É interessante este contato, pois o MSN não deixa de ser um contato mais pessoal até que o Twitter, pois você precisa dar. No Twitter, acontece uma inversão de valor que a pessoa quiser, porque você não precisa mandar o convite como no Orkut, você precisa adicionar, aceitar um amigo. No Twitter não, as pessoas te seguem sem você conhecer, falando para pessoas que não se conhecem e que tem opiniões diferentes que as suas. Esse relacionamento tem que ser bem pensado porque nem todo mundo vai concordar com o que você vai falar, ainda mais a partir de um momento que você tem muitos seguidores. Qualquer coisa, um bom dia já desagrada alguém. Tem que ser maleável, tem que saber como comunicar. Mas para mim é ótimo! Vou dar um exemplo como os seguidores são ativos e legais: ano passado eu trabalhava em uma agência, morava em Santos e trabalhava em São Paulo, ia e voltava todos os dias. Cheguei em São Paulo no trabalho de fretado, botei a mão no bolso e esqueci a carteira em casa, mas depois precisava voltar para Santos e não tinha o dinheiro da passagem. E agora para voltar? Eram 20 reais. Coloquei no Twitter, trabalho na avenida Paulista e será que alguém pode me emprestar vinte reais? Um monte de gente se disponibilizou a me emprestar dinheiro e encontrei com um cara na frente do McDonald's que me dou 50 reais. Eu consegui pagar a passagem e até hoje não o paguei, porque não sei quem é ele, ele nunca se comunicou comigo e nem falou que eu estava devendo. Hoje, mesmo aqui na Campari, estava com umas ideias de passar umas coisas na parede com o projetor. Eu coloquei no Twitter, alguém pode me emprestar um projetor. Um cara veio até aqui e trouxe o projetor, me entregou na minha mão, totalmente desconhecido. Fiquei de devolver no domingo. É uma relação de confiança que a pessoa acaba estabelecendo. É bem interessante.

V - Como você se comunica com seus amigos reais?

M - A gente sai para beber principalmente.

V - Você entra em contato com ele pelo Twitter ou celular? Como é? 
M - O principal é o celular, porque meu Twitter está impraticável para conversas pessoais. Celular, SMS, ligação mesmo e o MSN que é uma conversa mais pessoal.

V - Você está com uma vida profissional mais estabelecida, e a velocidade do material que você trabalha é muito rápido, os conteúdos na internet, o Twitter é instantâneo. Isso mudou de alguma maneira seu relacionamento com as outras pessoas?

M - É difícil responder... porque eu, obrigatoriamente pelo trabalho, blog, eu tenho que ficar muito tempo na internet. Se eu fico um dia sem atualizar, o pessoal reclama: ' $O$ que você aconteceu, você morreu?' 'Por que você não está postando?' 'O que aconteceu?' $E$ como eu montei o blog sozinho, eu sou escravo dos meus leitores. Eles querem ver coisas todos os dias e eu quero publicar coisas todos os dias. Essa dependência que eu tenho da internet, não é só porque eu gosto, mas pelos outros que querem ver conteúdo novo a todo momento. Eu tenho que estar antenado, pois saiu um vídeo tenho que publicar antes dos meus concorrentes. No meu blog, eu tento colocar tudo antes de todo mundo. Eu recebo de 300 a 400 e-mails todos os dias. Eu tenho que ler tudo, é bem complicado! É correria! Eu preciso acessar meu celular 3G, o computador fica direto ligado, é uma dependência mesmo.

$\mathrm{V}$ - O que você vê de principais vantagens e desvantagens da velocidade destas conexões de rede?

M - A vantagem é que você consegue falar com as pessoas a qualquer momento. Com seus amigos ou inimigos, e falar com os inimigos é ainda melhor porque ele não está perto. A parte ruim é a falta de contato humano com as pessoas como era antigamente, com o meu pai, quando ele tinha que ir até a pessoa e olhar olho no olho. Não existe tanto isso hoje em dia.

\section{V - Você sente falta disso?}

M - Eu já cresci no mundo da internet. Tenho um computador desde 1996, então, não posso dizer que sinto falta, porque eu não conheço outro mundo. Já no bate-papo da UOL já existia uma comunicação precária, mas era uma comunicação virtual. Creio que para mim não faz falta.

V - Muitas pessoas dizem que os meios de comunicação digital estão aproximando as pessoas. Você acha que isso acontece ou não?

M - Isso dá uma discussão durante umas duas ou três horas. Na minha opinião, eu acho que aproxima as pessoas, você conhece novos amigos e principalmente aqueles amigos que não teria a oportunidade de reencontrá-los.

$\mathrm{V}$ - O que você acha que tem de tendências para as redes sociais?

M - Orkut morreu há mais de 1 ano. Twitter é a "coqueluche" do momento e vai ser durante um tempo, mesmo porque algumas pessoas estão começando a conhecer agora. Vários famosos tem Twitter e acaba popularizando a ferramenta. O Facebook, embora seja mundialmente famoso, no Brasil está "pegando para valer agora". O futuro será uma integração de todas as redes sociais e que seja mais filtrada pelas pessoas através de seus bairros, faculdades. Você não vai acontecer apenas pessoas do sudoeste do Acre, mas se comunicar com seu vizinho por vídeo, todo tipo de rede, voz, imagem. Terá uma 
rede social só. Eu acho que está faltando isso que não é difícil fazer, mas é difícil comportar. Em breve, já deve ter isso.

Fabiana, 23, web designer.

V - "Vício" seria quantas horas por dia?

A - Eu não desconecto, né. Eu tenho "mobile". Não desconecto nunca. Se perguntar pra mim quantas horas estou conectada... Tô acordada, tô conectada. "Popa" mensagem aqui do Facebook, "popa" mensagem do Twitter, "popa" quando alguém me cita no Twitter, "popa" quando recebo e-mail, o celular vive "popando", então tô sempre conectada.

V - Mas, quais são as principais?

A - Olha eu participo do Blip para postar música no meu Twitter e no Blip. Eu participo do lastFM pra sincronizar tudo que eu escuto. As pessoas reclamam quando eu desligo o meu scrobbling lastfm porque muita gente conhece bandas de acordo com o meu lastfm. Eu tenho Flickr eu tenho Tumblr, eu tenho weheartit, aquele de fotos que você gosta. Eu tenho o Mizo que é sobre viagem. Você monta sua viagem fala sobre os lugares que você passou ou que você quer visitar... faz uma lista. Eu tenho Linkedln. Nossa tem tanta rede social. Tem o buzz, o reader acabou virando uma rede social. Tudo isso.

V - Bom, já tem uma diferença: uma lá longe, outra tá perto e a relação de vocês é mediada pelo computador. Mas alguma coisa interessante fica. Que negócio é esse?

A - Não tem diferença emocionalmente. Pode ser que fisicamente tenha muita diferença. Emocionalmente não tem diferença. Pra mim o emocional vale muito mais do que o físico. Eu e minha mãe, por exemplo, a gente sempre se deu supermal, depois que a eu fiquei 'aborrecente', chata, a gente brigava todo dia. Todo dia era uma briga horrorosa. Ela mudou pro interior, e a gente se vê muito menos... A nossa relação melhorou mil vezes, porque ela me manda um SMS bonitinho, eu vou e entro no messenger, a gente se conversa pelo Skype, ela tem saudades de mim. Não sei, melhorou nossa relação.

V - Interessante. Me conta um pouquinho de como são os diálogos via internet?

A - Depende. Alguns são bem rasos e objetivos, e outros são papo de mesa de bar, como você tivesse tomando uma cerveja que uma coisa puxa outra, puxa outra, puxa outra e você consegue passar dias conversando com as pessoas. É mais ou menos assim.

V - Há uma polêmica dizendo que algumas pessoas encontram mais pessoas através da internet, outras dizem que as pessoas se isolam mais. Qual sua opinião sobre isso.

A - Ah... eu acho que geralmente quem se isola muito através da internet é porque pessoalmente não tem muito motivo de estar perto de outras pessoas. Eu tenho amigos assim. São muito tímidos, cheios de si. Ah, não quero, não vou arriscar, ah, não quero namorar, tenho vergonha e tal. Isto é positivo pra pessoa porque é a única maneira que ela consegue se relacionar. Acho que não vale a pena você se forçar uma coisa que não é natural pra você. Então, eu tenho amigos que são assim, conheceram uma menina, conversaram anos e anos com ela pela internet, aí se sentiram confortáveis em se encontrar como amigos, viraram amigos pessoalmente, sabe. Pra algumas pessoas o contato pessoal é mais devagar. Isto não significa que seja pela época que a gente vive. 
Eu acho que é pela forma como a pessoa lida com a vida mesmo. Eu sou uma pessoa supercomunicativa, mas eu sofri muito com as pessoas porque eu sou uma pessoa coração aberto, conto coisas, já chego, ah se tiver que chorar eu choro na frente de todo mundo. Não tô nem aí. Eu sofri muito com terceiros. Então a internet me segurou mais. Eu conseguia conversar com a pessoa, com várias pessoas ao mesmo tempo sem me apegar tão fácil, e me apegando bastante com quem realmente me dava atenção, com quem era legal comigo. Mais ou menos isso.

V - Legal. Você disse pra mim que você está conectada permanentemente. Como é que é, quando você não consegue postar alguma coisa receber twitts ou mandar twitts?

A - Eu sinto falta... Mas, por exemplo, se eu estou numa viagem não é enlouquecedor pra mim não. Aí, nossa, eu estou morrendo, me faz muita falta. Agora se eu estou no mesmo tédio em casa e não passa nenhum programa que eu gosto na televisão, eu fico: "Ah... meu Deus eu preciso entrar na internet" porque lá eu vou encontrar alguma coisa que eu vou querer ver, que vai ser engraçado, ou que eu vou rir, vou chorar, que vai me interessar, e na televisão muitas vezes não. Ou: já fiz tudo que tinha que fazer, já limpei a casa, já fui lá visitar minha mãe, não sei o que, e eu tenho um tempo livre e eu quero curtir a internet e atualizar minhas coisas e tal. Se eu não consigo eu fico brava. Mas se eu tô ocupada, não faz falta não. Não tô doente por internet.

Giovana, 24, programadora.

V - Quais são os maiores desafios do seu trabalho?

M - Então, na verdade é exatamente este... a gente conseguir... Ah... porque na verdade assim... Ah... trabalhar com mídias sociais aqui no Brasil, começou... explodiu... assim ano passado... mas a gente meio já tava falando disse, eu saí né, no final de 2007 pra 2008, e assim lá trabalhei na primeira vez com mídias sociais. No Brasil, aqui e lá, do começo pra cá mudou demais assim... a gente fazia, ah, por exemplo, a gente meio que... até aproveitava das coisas que tinham audiência, das pessoas que tinham audiência pra divulgar alguma coisa, por exemplo, pagava uma pessoa que tinha uma comunidade no Orkut com muitas, muitas pessoas, ou então, pagava um blogueiro que tinha muita audiência. Hoje isso ainda acontece, só que assim, por exemplo, no Orkut não mais. Hoje o desafio é desenvolver ferramentas ou estratégias mesmo que façam com que as pessoas falem daquilo, sem a gente estar pagando todo mundo. Não assim pra gastar menos, assim realmente, as mídias sociais são conhecidas como uma vertente da publicidade onde se pagaria menos...

V - Dessas redes sociais, qual você usa mais? Pessoalmente.

M - Twitter. Hoje em dia com certeza Twitter. Eu tenho... tô todas, uso todas. E uso mesmo porque eu tenho que fazer entrevista de vez em quando pra saber o que está acontecendo ali. Como eu posso usar aquilo que tem de novo, como posso usar como ferramenta para trabalhar. Mas pessoalmente mesmo eu gosto mais do Twitter porque eu troco muita informação com muita gente, tanto pessoal como profissional. Ali eu tenho minhas subdivisões, meus grupos de amigos, profissional e tudo e é a ferramenta mais rápida que a gente fica em contato o dia inteiro todos os dias, 24 horas, e que dá mais possibilidade de espalhar qualquer ideia e de ter um resultado. Por exemplo, eu tô aqui, aqui eu tô fazendo uma cobertura para um outro veículo, eu quero essa agência, estou freelando pra um veículo. Então quando eu quero fazer alguma matéria, tem uma pauta, achei uma ideia de uma pauta quero achar pessoas tipo daí eu chamo pelo Twitter. Eu encontro rapidinho 
ao invés de eu sair ficar dando volta perguntando quem sabe... então o Twitter é uma mão na roda assim, profissionalmente, pessoalmente é a melhor.

\section{V - Pessoalmente como é que é o seu uso do Twitter?}

M - Ah... pessoalmente eu aprendi com meus amigos... na verdade quando você começa a trabalhar com mídias sociais, sua vida pessoal e profissional meio que se mistura... Entendeu?... O pessoal que você conhece das agências, na verdade, pra mim é engraçado, eu entrei... eu fiz um blog há 5 anos e comecei a trabalhar com isso, e por causa disso, e começar a viajar e conhecer pessoas e fiz meus amigos de Americana lá. Porque antes de vim para São Paulo, meio que conheceram o pessoal da agências, então a gente vindo... é... e meio que misturou, meus amigos pessoais e meus amigos de agência se conheceram se misturaram. Então pra mim tudo é a mesma coisa. Todo mundo acaba se conhecendo, fazendo amizade. Mas eu uso um exemplo... um exemplo tonto assim: outro dia eu tava em casa e queria saber se o mercado tava aberto e aí eu não conseguia encontra o telefone em lugar nenhum pra saber, não tinha o horário no site, e eu peguei perguntei no Twitter: 'Alguém sabe se o mercado $X$, na rua tal está aberto, né?' Não, acabei de sair de lá, tá aberto. Então, entendeu? É uma coisa assim que seria uma informação que você não teria como... A não ser que você pudesse pra um vizinho e falar: 'Ó, olha da janela vê se está aberto.' Isto você consegue pelo Twitter, assim... é legal.

V - Legal... As pessoas com quem você conversa durante o dia são as mesmas pessoas com que você encontra?

M - São. Assim... é... quando eu tô... na verdade assim... justamente por este negócio de eu me encerrar tanto, não interessa onde eu tô assim... se eu estou aqui trabalhando vou combinar com meus amigos qualquer coisa do meu trabalho e é com elas que eu vou sair. Aí se eu vou para minha cidade, meus amigos lá também têm, a gente combina via Twitter, via rede e se encontra lá e tá. Então, tanto sendo meu amigo e sendo da área profissional, sim, as pessoas que converso durante o dia via rede são as pessoas que vou sair à noite.

V - A sua maneira de se comunicar com outras pessoas ou de estabelecer contato com elas depois que você ficou mais acostumada com a velocidade dos Twitters, por exemplo, coisas instantâneas da era digital, ela mudou?

M - Eu acho que mudou, mas se você me pedir pra falar o que mudou, eu não sei se vou saber falar. Porque assim... eu estou tentando... a gente conversa muito sobre isso: a gente tá tentando lembrar da época sem Twitter... a gente brinca... tem blog desde antes de existir Twitter aqui no Brasil até. Então a gente fica brincando, por exemplo, a gente ia pros eventos e ficava: "Nossa! Eu sou fulano do blog tal. É... e aí é uma coisa que assim... às vezes, o cara tinha uma fotinha assim que você... e agora, gente, pelo Twitter, por exemplo, tá convivendo com a pessoa diariamente ali, praticamente meio que conhece a pessoa e você pode tá colocando no Twitpic. Você tá vendo tudo que ela tá colocando, tudo que ela tá falando. Às vezes, por exemplo, tem gente que chega assim, já aconteceu... É muito engraçado assim... Eu tenho vários followers assim, vamos dizer. E já aconteceu, por exemplo, de eu estar sexta-feira... eu sempre falo: sexta-feira eu vou viajar, eu vou pra [cidade natal], tô indo lá, não sei o que... Aconteceu de uma vez eu estar no ponto de ônibus, um cara chegou e disse assim: "Ah... dá licença... você é a [Giovana] do blog, não sei o quê... Aí era sexta e eu tava com mala. "Tá indo pra Americana, né?". Então assim, é engraçado que o pessoal cria uma intimidade que assim eu tive que aprender a não me assustar com isso. Porque se eu estou expondo, as pessoas tão vendo, se as pessoas tão vendo, eu não posso simplesmente achar estranho o fato delas 
saberem as coisas. Então, se o cara de repente me fala: "Você tá indo pra [cidade]", e eu "twittei" de manhã que eu tava indo pra Americana, eu não vou olhar pra cara dele e falar: "Seu maluco tá me seguindo!" Pô... ele me conhece... ele sabe... [rindo] eu falei, eu abri. Então acho assim: a partir do momento que você abre, você tem que aprender a ter muito jogo de cintura e não achar a coisa estranha. Sabe porque... se você não quer que ninguém saiba, que ninguém te aborde, que ninguém fale da sua vida... não exponha... tá?

Helen, 32, game designer.

V - Quais são as vantagens e desvantagens de "estar" e "não estar"?

C - Olha, eu prezo muito o contato pessoal. Quando eu comecei, e até hoje é assim o meu Orkut, eu só adicionava pessoas que realmente conhecia. Ao contrário de pessoas que querem angariar número, né, eu tenho mil amigos. Não, o meu Orkut deve ter umas 200 pessoas, sei lá, ou 300, não sei. Mas são pessoas que eu conheço de verdade... que conheço pessoalmente. Todas, né. Estudaram comigo, trabalharam comigo, enfim. Pelo menos eu conheço... Podem não ser profundos amigos, mas eu conheço, entende? É, eu acho que é a primeira premissa da rede social é reencontrar pessoas que você já teve contato. E abre esta possibilidade de você conhecer pessoas novas que você nunca teve contato. Eu tô aqui ao meu lado com duas pessoas que eu conheci pela internet que hoje em dia fazem parte da minha rede de contato, que já conheci pessoalmente, nos encontramos em vários eventos, fizemos parceria juntos, mas que conheci pela internet. Eu acho bacana... O bacana das redes sociais é isto. É você socializar, né? As pessoas, antigamente, quando não tinha rede social, o que elas faziam?... la pra balada... né... Aí conhecia a pessoa lá e trocava telefone. Houve uma época que existia uma brincadeira não sei se você chegou a passar por isso -, que era o telefone... você discava prum telefone tava ocupado... era a linha cruzada... e você tava falando com todo mundo na linha cruzada. Isto era uma rede social. Rede social é um contexto. Ela não é dependente da internet. Ela é independente da internet. E o ser humano tem esta tendência de querer socializar. Então a internet só facilitou, né. Porque, por exemplo, falar por telefone, por carta... por carta é demorado, por telefone é caro... Então, a internet todo mundo tem. Hoje em dia se tornou uma coisa muito mais fácil, né. Então você socializa, você encontra pessoas que têm coisas em comum com você... É óbvio que todo mundo só quer se encontrar com pessoas que tem alguma coisa em comum, né... Não vou encontrar com pessoas que não tem nada a ver comigo... não tem nem o que falar. Não tem nem assunto, né. $E$, neste caminho as pessoas perceberam que elas poderiam ir além do apenas diversão, né. $E$ entrou a questão até mais profissional, as pessoas começam a se divulgar, né. A divulgar o seu lado profissional, e as empresas divulgarem também. Tem muita gente que hoje em dia usa estas redes... "Pô, tô desempregado aí galera... saí da empresa... eu faço isso, isso, isso... quem souber de alguma coisa... E este relacionamento é uma pirâmide de cabeça para baixo, né. Ela tem um início e não tem um fim... é infinito. Então em algum momento você tira uma vantagem desta situação, né... de conhecer pessoas, né. Então acho que a rede social se tornou isso... É um relacionamento de diversão e profissional. É a minha visão.

$V$ - As redes sociais estabelecidas através da internet, pela própria velocidade do meio e pela facilidade que o mecanismo tecnológico permite os contatos, ele me parece potencializar os contatos em rede, mas será que estes contatos estabelecidos chegam efetivamente a estabelecer relações?

C - Olha... aí vai depender do que você entende por "relações", né. É... relação de amizade... Outro dia estava vendo aqui na campus party uma palestra muito interessante... 
O pessoal tava falando comigo sobre a confiabilidade da internet, e uma pessoa levantou e questionou, mas não se pode... a gente tem uma ilusão de confiança. Por exemplo, a gente acredita que vai tá vivo amanhã. Pode ser que não esteja, né. A gente acredita na economia do país, a gente acredita nos nossos governantes, ou não né. Mas a gente tá seguindo, né, numa crença de certa forma. Então, é... e relações?... Se você tem um contato, você troca alguma coisa... isto já é uma relação. Relação tem vários níveis, Eu... eu pelo menos faço isto na minha vida real. Pessoas que eu conheço, não necessariamente eu digo assim: essa pessoa é meu amigo. Não! É um conhecido, é um colega, né. É um amigo, é um amigo íntimo, né. Tem níveis. Eu acho que na internet também tem isso. Eu conheço, falando, também de relações... Pessoas que inclusive teve relações amorosas. Tem uma amiga que conheceu um rapaz pela internet numa sala de bate papo... casou, estão superfelizes, né... E, então, o cara superbacana. Você consegue encontrar boas pessoas... porque todo mundo fala: "Ah... internet é perigoso, não sei que..." Ser humano, gente! Você tá lidando... não é máquina... As pessoas tem a tendência de... "A internet", "A internet". Não é. Existem pessoas por trás do computador, existem pessoas por trás da internet. São seres humanos e seres humanos podem ser bons ou maus, né. Aí, a mesma coisa que a pessoa pode fazer com você pela internet, ela pode fazer com você na vida real. Você é que tem que analisar como a pessoa tá agindo contigo e ver se está sendo bacana ou não... né... Até aonde você pode ir com aquela pessoa. Eu acho que relação existe. Existem níveis, né. É isso.

\section{V - Em que sentido você sente afetada?}

C - Olha, me sinto afetada por completo. Tem dias que você fica a ponto... estressado. Você começa a ficar muito agitado. Eu tenho feito atualmente um trabalho e... inclusive monitorar meu tempo em relações a estas ferramentas. E já que eu tenho uns relacionamentos que me facilitam o processo, e eu tenho uma sócia que trabalha comigo pra... no caso, nesta questão de mídias sociais pra empresa. Porque você chega no final do dia, você sai extremamente ligado, você tá agitado, né. Porque a velocidade de informação é tanta e você, às vezes, chega a ponto de você começar a ter falha de memória. É como um copo que você vai enchendo, enchendo, enchendo... as coisas vão transbordando. Entra uma coisa mas tá saindo outra. Você... é muito informação. Você tem que começar a filtrar. O que serve pra você e o que não serve. Até onde eu vou com o meu estudo, né. Ainda tem isso. Porque se toda hora eu entrar em todas as ferramentas eu vou ficar louca. Então eu tenho que começar a filtrar, quais são, realmente, as ferramentas efetivas que estão no mercado e focar só nisso. E eu passei a fazer só isso e oferecer só... Olha para este tipo de público ofereço isso, aquele... você quer outra ferramenta, você procura então outro profissional... Senão... eu tenho que saber tudo e nenhum ser humano sabe tudo, gente. Por mais que queira, a gente não é uma biblioteca... ainda não existe um chip na minha cabeça. Então eu comecei um processo de desaceleramento, né... Porque essas redes sociais, você principalmente estar em todas, eu acho que a mais frenética delas é o Twitter, né, você fica extremamente acelerado.

V - De que maneira assim, pessoalmente falando, você se sentiu afetada?

C - Questão... olha... Eu já estava pensando em 140 caracteres. Isto foi a parte que eu me senti afe[?] eu via um negócio na rua.. eu pensava ligar pra um amigo pra comentar ou chegar em casa, porque eu divido apartamento com amigos, chegar em casa pra comentar... eu já pensava assim... em 140 caracteres... é... [risos]... pra eu rir. Eu falava pra pessoa... sei lá... eu ri... é... eu falava pra pessoa pá, pá, pá, pá.. eu ri... ou então, k, k, k, k, k. Eu já comecei a falar essa lin...eu falei: NÃO! PARA! Para que agora você está enlouquecendo. Pode parar porque aí já chegou o limite, né... $\mathrm{E}$ eu tava muito acelerada. 
Eu sou geminiana, já falo rápido, acelerado então não tava dando certo, né. Você fica agitada a ponto de perder o sono mesmo, quando você vê já são 4 horas e você está na internet ainda, sabe... pra acordar às 6 no dia seguinte.

$V$ - As pessoas dizem que uma das coisas que se perde na internet, nas relações mediadas pelo computador é a ênfase, por exemplo, no diálogo. Que outros tipos de empecilhos você acha que são desafios também pra comunicação e pras redes mediadas pela internet?

C - Olha, esta questão da ênfase realmente pega um pouquinho, né [riso]. Mas eu acho que tem subterfúgios bacanas que você quebra isso. No caso... solta uma piada... se for na forma textual se você soltar, pode parecer uma coisa venenosa ou pode ser uma brincadeira. Você quebra isso como? Uma caretinha. Bota dois pontos e um "P" e bota uma careta. Ou você bota risos. Ou então você sabe que a pessoa tá brincando ou tá te sacaneando, não tá sendo maldosa, ela tá brincando. A outra questão, e aì eu acho que essa aceleração da internet trouxe de ruim, é que as pessoas estão desaprendendo o português. Se você sabe escrever bem, então não existe mal-entendido. Eu vejo desta forma. Eu falo pras pessoas e até riem: eu me expresso melhor escrevendo do que falando. Incrível! Mas é. As pessoas me entendem melhor quando eu escrevo porque eu tenho um bom português, mas quando eu falo, eu falo de situação, falo utilizando muita gíria, fazendo careta... Então assim, (quando estou entre amigos, eu tô falando), então às vezes as pessoas acham que eu não tô falando sério ou acha que eu tô... ou acha que eu tô falando sério... Porque quando eu vou fazer uma brincadeira ou contar uma piada, eu fecho a cara. E a pessoa leva a sério. Aí eu começo a rir, entendeu, pra mostrar, entendeu, que eu tô brincando. Falo: "Pôxa... você não viu que era óbvio, uma piada, não?", "Tá falando sério?", "Sim... mas tá falando sério uma coisa idiota, então é uma piada" . Então eu tenho até esta dificuldade de falar. Eu prefiro escrever. Se a pessoa escreve bem e sabe usar os subterfúgios que a internet criou para resolver esta questão da ênfase isto não torna empecilho, não.

Ingrid, 54, historiadora.

V - Me conta um pouco sobre a sua palestra que você acabou de dar.

MG - Bom... eu tentei... A palestra que eu dei foi resultado de um Projeto [...] que eu tenho a coordenação nacional dele desde 2008... que eu coordeno este projeto. É um projeto na área da saúde, trabalho e cultura e é um projeto de inserção digital. Este projeto de inserção digital se utiliza... tem como dispositivo a cultura digital, uso de celulares, da máquina fotográfica, onde os trabalhadores utilizam isso para se autorrepresentar. E tem todo um processo de reflexão sobre esta autorrepresentação, de discussão, de elaboração, de entendimento disso. E depois de condições de alternativas. E depois de todo esse processo, então, existe a construção de redes sociais. Então nós temos hoje quase setecentos trabalhadores inseridos numa rede discutindo sua vida, seu trabalho, construindo alternativas e construindo redes de comunicação e discussão de cidadania.

\section{V - De onde partiu o processo de construção deste Projeto?}

MG - Este projeto surge como demanda dos trabalhadores. [em um congresso] que ocorreu em 2005. Uma das principais demandas dos trabalhadores era a visibilidade. Seja a visibilidade das condições de vida, seja a visibilidade das condições de trabalho. Mas eles queriam uma visibilidade não a partir do olhar do técnico, mas a partir do seu próprio olhar. Então, a visibilidade deste projeto está sendo construída a partir da 
autorrepresentação dos trabalhadores sobre sua vida, seu trabalho. Trabalhador é sujeito e objeto da sua própria construção desta visibilidade.

\section{V - Bom... é... os trabalhadores são treinado para usarem o instrumento tecnológico?}

MG - São. Os trabalhadores...eles têm um... A gente se utiliza da educação popular como principal referencial teórico do processo de formação. Então nós utilizamos a educação popular que tem um pressuposto fundamental para a construção do conhecimento de forma coletiva. E esta construção do conhecimento se dá de forma coletiva e ao mesmo tempo se discute de uma forma mais crítica a realidade e se constrói alternativas a respeito. É todo um processo de formação que utiliza do pressuposto teórico da práxis. Ou seja, da ação, da reflexão e de uma nova ação. Este é o principal pressuposto teórico. Os trabalhadores, eles são capacitados para a utilização do vídeo, da máquina fotográfica, do celular (eles usam o celular) e depois desta utilização da inserção disso no site e no trabalho em rede. Então eles tem uma primeira formação que é essa. Mas a formação é continuada. De 15 em 15 dias eles se encontram com uma rede de apoio (com a rede), onde a universidade participa... mostram o que eles produziram. Colocam qual é o significado daquilo que eles produziram. E a partir do olhar da produção de um, se discute o todo. Porque, de um modo geral, a produção de um tem que ver com a produção de todos. E a partir deste trabalho, da produção de um, da história de vida de um se discute $o$ todo... discuti as questões mais gerais. E depois deste trabalho que é feito de $15 \mathrm{em} 15$ dias tem toda a construção da rede social, onde também é o processo de formação, de troca, de discussão, de intercâmbio, de relações que se dão... Então nós temos um processo de formação contínua presencial e também na internet, virtual.

V - Perfeito. Muitas discussões feitas, tanto presencialmente, como pelas redes sociais, elas originam alguma ação?

MG - Muitas. Pra se ter uma ideia. Um estado, Rio Grande do Norte, um trabalhador, por exemplo, ele era do Sindicato dos Comerciários. E aí ele fez uma denúncia: falta de local de descanso. Tirou uma foto e colocou na internet. Isto mobilizou o Ministério Público do Trabalho, e fez uma ação neste mercado e mudou completamente a situação de vida. Isto é um exemplo de várias situações. Hoje o Ministério Público do Rio Grande do Norte entra diariamente no site para ver se tem alguma denúncia para fazer uma ação de fiscalização. Por um lado é isso. Por outro lado, por exemplo, tem ações de solidariedade. Uma coisa muito bonita. Tem uma prostituta que tá no DVD que é a Maria da Paz e ela coordena o sindicato, a associação delas... E ela começou a fazer uma ação de busca de familiares de outras moças que também eram prostitutas e que tinham se perdido dos pais. Porque no Nordeste é muito comum uma menina ser vendida e nunca mais ter contato. E hoje um processo, um projeto dela, pessoal, através do [projeto] de busca de familiares de outras prostitutas no interior do Nordeste. Aí elas fazem encontros... tem por exemplo... que outras ações existem... existem ações de alfabetização. Tem pessoas que não são só analfabetas digitais. Elas não sabem ler. E através do projeto elas estão buscando o processo de alfabetização para poder participar mais do projeto. Então tem ações dos mais variados tipos, desde do sindical até a questão humanitária. A questão da solidariedade, da troca, da amizade. Então é uma rede que não é fechada. Eu digo, uma rede do cotidiano de vida. Se for entrar é do cotidiano. É o cotidiano de vida de muitas categorias que estão nesta rede trocando.

$\mathrm{V}$ - O uso da internet dos meios digitais desses trabalhadores são feitos a partir da onde? De casa? Do trabalho? Da lan house? Como é que é? 
MG - É... muitos são através de lan house, mas também, por exemplo, o projeto desencadeou alguns processos de doação de computadores. Trabalhadores muito pobres que não tinham possibilidade de acesso e que moravam muito longe... A Receita Federal, ela às vezes consegue computadores e, através do Ministério Público, o do Rio Grande do Sul recebeu 8 computadores e doou para os trabalhadores mais pobres para eles poderem ter mais facilidade de acesso. Mas não é lan house. Os celulares são comodato. Não são deles. Eles recebem os celulares e usam enquanto estão participando do projeto. Se eles saem, eles dão pra outro trabalhador. Estes celulares são da [universidade]. A gente tem 643 celulares. Enquanto o trabalhador tá participando, ele tá usando. Se ele não participa, ele passa pra outro trabalhador.

V - De que maneira você consegue observar, enquanto participante ativa desse... organizadora desse processo todo... de que maneira se alteram os vínculos a partir dessa relação com tecnologia?

MG - É... é muito interessante... Eu acho que a grande característica deste projeto é a inclusão digital de uma forma diferenciada... Porque ele constrói redes e constrói relações... o caracteriza... confecções novas. Vamos usar o novo: relações. Relações diferenciadas que se estabelecem entre os trabalhadores. Relações que eles nunca imaginavam. Eu lembro quando um trabalhador diz o seguinte: "Olha, eu mudei minha percepção, meu preconceito racial, profissional." Existia durante muito um certo preconceito contra o trabalhador informal: catador de lixo, pescador... e num trabalhador formal. Existia uma certa diferenciação de classe, e hoje, eu acho que isto está completamente diferencia... eles falam isso... a voz deles é assim: "olha eu não imaginava como isto ia mudar minha vida". Porque hoje são relações solidárias e são relações horizontais que se estabelecem entre todos que participam da rede, é o médico e a enfermeira, agente comunitário, é o pescador, o catador de lixo, é o comerciário, metalúrgico mostrando uma rede diferenciada de relações. Eu acho que aí não sei dizer qual é a dimensão total disso, mas é uma grande dimensão... Grande de relações diferenciadas.

$\mathrm{V}$ - Neste sentido, quais seriam os nossos maiores desafios daqui pra frente?

MG - Primeiro abrir... o projeto porque ele tá muito limitado... Nós temos que abrir. Segundo buscar a sustentabilidade deles, que eu acho que é importante. E terceiro aprofundar isso... Aprofundar essa possibilidade... porque este projeto também está desencadeando políticas públicas. Quando, através de uma denúncia, tu vai no Ministério Público, tu vai no Sindicato, tu vai no Ministério da Saúde, tu vai na Vigilância para que eles façam uma ação de vigilância para diminuir aquela situação, aí estão documentando, está atrapalhando a vida, nós estamos construindo políticas públicas. Então ter este espaço de construção de políticas públicas é muito difícil. Porque também historicamente quem participa da construção das políticas públicas não são os trabalhadores de bairro. $E$ nós trabalhamos com trabalhadores de bairro, não trabalhamos com reversão de sindicom. Então manter essa abertura, essa possibilidade de que esses trabalhadores possam ter um espaço para poder participar das políticas públicas, para poder construir, tenham resultado e que pensam efetivamente atores desse processo, eu acho que é um grande desafio. E eu acho que poder analisar tudo isso e ver o que está acontecendo, porque é muito bonito... é muito bonito. Você tem que entrar no site pra ver. E veja estes vídeos sem fala que tem situações muito interessantes... 
João, 22, desenvolvedor.

V - Explica um pouco a "Robótica Livre" e a "Metareciclagem" pra gente.

G - Bom, "Metareciclagem" é um movimento auto-organizado de pessoas de tudo quanto é área, desde biólogos, engenheiros, que veio trazer o estudo acadêmico pra uma coisa informal. Trazer da formação pra informação. E liberar os estudos e pesquisas mais para 0 terceiro setor e pra... fizemos muito trabalho pra cooperativa, redes... com escolas ... tentando fazer oficina usando lixo eletrônico. O pilar da "Metareciclagem" no começo foi uso de material de sucata mas, depois, outras pessoas, que não são do ramo de tecnologia, começaram a pensar no estudo, por exemplo, lixo eletrônico... Você pode pensar em reutilização então você precisa de nerds e pessoas que entendam de informática, mas quando você vai trabalhar com materiais e tentar fazer artesanato, por exemplo, sempre tem o risco de você mexer com material tóxico. E aí pessoas com estudos nesta área de lixo eletrônico... como que ele prejudica o solo e como que prejudica as pessoas começaram a se interessar também e a rede começou a ganhar um leque de interessados, de pesquisadores. $O$ "Robótica Livre" ele traz também... eles são bem parecidos neste aspecto de informação, porque ele traz um pouco da didática no ensino e na construção dos "robozinhos", e sempre tentando trabalhar com sucata com um mínimo de custo possível. Tem muito projeto acontecendo com escolas públicas que não tem dinheiro pra comprar esses kits já pré-produzidos. Outra vertente que... a gente já tem um lance de um kit pré-produzido... O cara sai sabendo programar naquela linguagem que ele nunca vai encontrar no mercado de trabalho dele e nenhuma pesquisa ele vai conseguir desenvolver. Então, já trabalhando com este tipo de material, sucata e "hardware livre", o cara pode tanto começar a fazer pesquisa por conta própria ou iniciar um laboratório.

V - Neste contexto, como é que surge a questão do "Soft livre"?

G - "Soft livre", ele vem como ferramenta pra embasar nossos princípios de liberdade tanto de ideias, de pré-conceitos. E como a gente tenta hackear [o termo vem de hacker] primeiro os computadores que não tem hardware livre... Hardware do Windows que a gente trabalha na robótica, então a gente faz uma hackeagem do material que a gente já tem. Então... a gente tem uma computador velho e quer transformar ele num osciloscópio, então uma ferramenta pra análise de laboratório de eletrônica. É uma ferramenta supercara, e você pode usar um computador 386, um " $X$ dinossauro" qualquer e transformar num osciloscópio de precisão de eletrônica, não de elétrica mas pra níveis de eletrônica você consegue trabalhar super bem com uma precisão muito parecida. Você não gasta grana com isso, você só trabalha com soft livre, pode colocar em laboratório de escolas públicas sem problema nenhum e oferecer oficinas. Então tem muitas redes e institutos que financiam pesquisas pra galera que está iniciando mesmo. Então é muito fácil achar o pessoal que está... mesmo na oficina de "Robótica Livre" se interessou em continuar a pesquisa, e oferecer a oficina é uma forma de continuar esta pesquisa e se sustentar neste meio... Meio difícil de achar alguém que banque e acredite nesta área de pesquisa. Então, redes, SESCs, institutos conseguem fazer isto bem feito.

\section{V - E você tem versatilidade com redes sociais, comunicadores instantâneos?}

G - No projeto que eu trabalho da cidade de São Paulo, existe a 'Rede de Projetos', que é um cluster por onde os pontos... os inconscientes se encontram. $O$ pilar dela é um site, um grupo, que as pessoas documentam os projetos. Então, raramente essas pessoas se encontram, mas o dia a dia é produção neste site. Blog, fórum e hiperdiscussão... E aí 
eles, por conta própria, criam muitas comunidades com referência nos projetos. Porque os projetos podem ser desde artesanato e... mas eles envolvem tecnologia. Então, a pessoa pode usar o InfoCentro que ela trabalha para desenvolver um projeto de artesanato. Mas em algum momento ela tem que documentar isso e criar um blog e colocar este artesanato on-line. Então a tecnologia não fica meio empecilho pro cara. 0 cara não tem que aprender tecnologia, mas tem que usar como alavanca pra ideia dele. $E$ o site 'Rede de Projetos' é um cluster pra galera trocar informações, trocar figurinha, mas não fica preso também a este site, é só um ponto de encontro. Muitos projetos são desenvolvidos via Orkut, Facebook, e tem muitos projetistas que usam o Twitter pra divulgar os projetos, né. Fora a galera que é mais iniciada do Metareciclagem, isto já é de praxe.

V - Das pessoas que você conversa cotidianamente através dos meios digitais são as mesmas pessoas que você encontra?

G - Pouquíssimas... pouquísimas. Os encontros acontecem, por exemplo, aqui uma vez por ano... é... Mas acho que $10 \%$ encontro no cotidiano. Mas a conversa, a maioria desenvolvimento conversa cotidiana rola direto.

V - Um comentário comum que eu tenho ouvido falar ultimamente é de que a velocidade com que a comunicação se estabelece através dos meios digitais ela é muito rápida, você tem esta impressão também?

G - Eu tenho essa impressão... Eu tenho um contraste assim em casa... Você fica no Twitter e aí você vai conversar em casa a semana [ele quis dizer notícia] chega uma semana depois. A notícia mais top. Já aconteceu... $\mathrm{E}$ aí tem a brincadeira: "Ah... isto é tão semana passada, né!". Quando alguém vem falar alguma coisa pra você. Então, Twitter vem a informação muito rápida, muito filtrada. Raramente leio jornal assim pra... você tem que absorver... segue quem... Se você tem interesse, você já filtra a informação por aí. E sem excesso nem com ruído, são irritantes no seu cotidiano.

\section{$V$ - Em que sentido isso interfere na maneira como as pessoas se relacionam?}

G - Acho que principalmente, pô... vai: televisão. Já não sinto necessidade de assistir televisão, então você já não se relaciona com quem tá conversando sobre programa de TV. Então isso é bem drástico assim no cotidiano. A galera começa a conversar sobre programação e você já não vai misturar com esta rede. Você não faz parte mais. Acho que isto é o principal.

V - Você está dizendo que você começa a filtrar as pessoas de acordo com os interesses, é isto?

G - Acho que não filtro... acho que é uma... Não é você que filtra. Acho que são as próprias pessoas por interesses que... é... sintonia. Você não tem assunto pra puxar com aquela pessoa então, eu não crio o filtro. Não é que eu coloco uma rede e vou procurar as pessoas. Mas é que não rola uma comunicação justamente por não ter um interesse em comum. Não existe uma ligação em comum entre esse grupo.

V - Como é que você acha que tá o panorama assim das relações tendo em vista esta velocidade com que a gente se comunica através dos meios digitais. 
G - Bom... acho que existe muita inovação de um dia pro outro. A gente tenta estabelecer estudos sobre redes sociais e depois de 3 meses começa a cair por terra. Você não tem mais esta referência, e a gente tá muito no meio da lama, né... A gente tá no meio... tá afogado e tentando ajudar a galera. Então tem muita gente que se diz doutor em redes sociais, mas o cara está inserido no mesmo meio, ele não tá no patamar de dar orientação. Acho que tá todo mundo no mesmo barco, não tem ninguém assim com referencial, com uma perspectiva diferente. Acho que tá todo mundo inserido numa... é uma ecologia né. Pra você fazer parte da rede você tem estar no meio. Você não pode estar ficando de fora. Você tem que estar inserido. Então não tem um cara melhor que outro. Está todo mundo numa mesma rede. É uma teia só. São tudo pontos. Um pontinho daquilo e todo mundo tem a mesma possibilidade. Você cria um abalo e por mais longe que você esteja você está nesta rede também, este abalo vai ser sentido por todos. Então, não tem uma hierarquia diferencial, não tem chefe... Acho que a galera encontrou um "comum" de conversação, de comunicação e de... é um meio de vida assim mesmo. Você começa a estabelecer uma forma de se relacionar com as pessoas, isto influencia o seu jeito de ser. Então você começa a trabalhar em rede, você começa a viver em rede e isto começa o seu cotidiano. [ Talvez ele quisesse dizer: isto afeta, influencia o seu cotidiano].

\section{$\mathrm{V}-\mathrm{O}$ que você tem como prognóstico das redes sociais daqui pra frente?}

G - Meu... eu enxergo muito... é... uma rede muito... tendendo ao "xamãnico" assim. Uma coisa "xamãnista". As coisas ficam cada vez... A gente vai percebendo cada vez que a forma de trabalho natural, né, como a natureza já se comporta, é o que a gente tá começando a aprender. A gente começa a desenhar o que a gente tá trabalhando hoje em dia por meio de como a natureza já atua. Ah!, então a gente está falando de redes sociais agora, pô isto é ecologia de fungos. Fungos se comportam assim. Clusters, né. Meio de sustentabilidade que eu acho que é o principal fator que a galera tá procurando nesses grupos de pessoas, como que eles são autossustentáveis. Isto é princípio natural, como qualquer micro-organismo se comporta. Então esta quebra de resistência que acho que é onde a gente sofre que vai ser o grande objetivo. A gente quebrar o sofrimento de tentar inovar alguma coisa. Não existe inovação. É a gente descobrir o que já existe, como que estas coisas funcionam. Não é criar coisas novas. É ver o que já existe e colocar isso num fluxo certo.

V - Neste sentido, quais seriam os principais desafios tanto políticos, econômicos quanto sociais para que isso ocorresse de uma maneira ampla?

G - Acho que o principal político é que o capital não sustenta de forma natural. Vai ser uma briga. $O$ capitalismo não funciona dessa forma, é outra história, então pra que esta ecologia natural funcione, não condiz com o capital da forma que a gente trabalha hoje. Então, isso vai ser o principal fator assim de sofrimento, tanto de gente e pra quem está na ponta da lança de brigar por isso, né. $E$ já vem acontecendo muito, né, desde da forma de tratar a informação quanto a forma como tratamos o nosso trabalho. $O$ nosso trabalho é vendido... De uma determinada forma, a gente faz escambo de uma determinada forma, mas por dinheiro, né. Então, talvez isso venha como uma visão de inovação mas que já é uma coisa superultrapassada. As comunidades sempre se relacionaram trocando o que precisavam, não acumulando algo... coisas fictícias. "Ah! vou acumular dinheiro." E tem muita gente que já tá... isto não é daqui tantos anos. Já tem muita gente trabalhando assim. Então a forma... O que você precisa pra trabalhar... seria o seu salário, né... você pode adaptar... não precisa ser dinheiro necessariamente. Você pode trocar por ferramentas, redes de escambo e que é uma sustentabilidade desta forma. Mas é uma perspectiva muito difícil de encarar, né. Porque a gente tá numa matriz, numa fôrma que 
não é assim... Ou você está dentro ou você tá fora. Você não trabalha se você não está encaixado neste formato. Então, (é uma visão minha) para que esta sustentabilidade aconteça tem que desinformar, e aí tem que ter um tanto de gente interessando em sair deste fôrma e trabalhar sem medo de colaborar, né. Então, por exemplo, meu... eu acho que... aí vendo notícias né, Estados Unidos sofreu muito né... A galera: "pô não vou votar neste cara porque acabou perdendo dinheiro". E a galera não tem essa visão de que, meu, a gente vai investir em uma coisa pra conseguir trabalhar de mudar a maneira de vida. Só que não tem gente disposta a trabalhar desta forma. Então você mexe no seu bolso aí você já não, não gosto dessa... Então tem gente disposta a trabalhar no colaborativo.

$\mathrm{V}$ - Nesse sentido as redes sociais auxiliam as pessoas que tem interesses comuns a se encontrar?

G - Eu acho que sim, principalmente porque isto começa a moldar o seu estilo de vida... então você inserido é... tratando as pessoas em comum nas redes sociais... é que nem você aprender a... a galera que aprende a pilotar um avião no simulador. Aquilo vai moldando. Vai criando um aprendizado. As redes sociais, você tem este patamar que não tem a hierarquia de... ninguém é melhor do que ninguém. E é uma forma diferente de você se relacionar com as pessoas. $E$ isto acaba influenciando o seu cotidiano físico. A forma que você trata, você pode puxar um cara que você acha supercelebridade lá no Facebook pra conversar daqui a pouco. Você encontra o cara no físico, na vida real aqui (na vida real!... tudo é vida real, mas), encontra no físico e conversa com o cara do mesmo jeito. Isto vai moldado a sua forma de conversa com as pessoas. $O$ caráter que você tem perante todos, tem uma forma de linguagem com todo mundo independente de quem ele seja. 